MT-DP - 2008/22

\title{
Leveraged Carry Trade Portfolios
}

\author{
ZSOLT DARVAS
}




\author{
Discussion papers \\ MT-DP - 2008/22 \\ Institute of Economics, Hungarian Academy of Sciences
}

KTI/IE Discussion Papers are circulated to promote discussion and provoque comments. Any references to discussion papers should clearly state that the paper is preliminary. Materials published in this series may subject to further publication.

Leveraged Carry Trade Portfolios

\author{
Zsolt Darvas \\ research fellow \\ Institute of Economics \\ Hungarian Academy of Sciences \\ E-mail: darvas@econ.core.hu
}

October 2008

ISBN 9789639796409
ISSN $1785377 \mathrm{X}$ 


\title{
Leveraged Carry Trade Portfolios
}

\author{
ZSOLT DARVAS*
}

\begin{abstract}
Studying all possible pairs of eleven major currencies and eleven portfolios in 1976-2008 we show that, when there is no leverage, carry trade is significantly profitable for most currency pairs and portfolios. Positive returns do not diminish in time providing a strong case against the hypothesis of uncovered interest rate parity. We explain these findings with the leveraged nature of carry trade: leverage may increase profitability but it materially increases downside risk. We argue that market inefficiency is related to the level of leverage.
\end{abstract}

Keywords: Bootstrap, Currency market, Diversification, Leverage, Uncovered interest rate parity

JEL: C32, F31, G11, G15

\footnotetext{
* Tel.: +361309 2652; fax: + 3613193136 .
}

E-mail address: darvas@econ.core.hu (Z. Darvas)

A shortened version of this paper is forthcoming in the Journal of Banking and Finance ( www.elsevier.com/locate/jbf ). The paper was written while the author was affiliated with the Financial Research Group of Argenta Zrt. I am thankful for comments and suggestions to Chris Becker, Craig Burnside, Markus K. Brunnermeier, Balázs Gál, Péter Hajósi and Zoltán Schepp. István Mák provided valuable help in data collection. Special thanks go to Levente Pápa for his advice on the operation of forward markets and long discussions of this paper, and to András Simon for his many suggestions to improve the paper. All remaining errors are my own responsibility. Financial support from OTKA Grant No. K 61221 is acknowledged. 


\title{
Tőkeáttételes carry trade portfoliók
}

\author{
DARVAS ZSOLT
}

\section{Összefoglaló}

Tanulmányunkban a tőkeáttétel hatását vizsgáljuk az ún. carry trade befektetésekre, azaz olyan devizaügyletekre, amelyeknél egy magasabb kamatozású devizát vásárolunk egy alacsony kamatozású devizával szemben. A világ tizenegy vezető devizájának összes lehetséges párosítását, valamint tizenegy portfoliót vizsgálva az 1976-2008-as időszakban arra az eredményre jutunk, hogy tőkeáttétel nélkül a carry trade szignifikánsan pozitív eredményre vezetett szinte az összes devizapárnál és portfoliónál. Rejtély, hogy a szignifikánsan pozitív hozamok hogyan maradhatnak fenn hosszú időszakon keresztül, és ezen eredmény erős bizonyítékot jelent a fedezetlen kamatparitás hipotézisével szemben. Véleményünk szerint a tőkeáttétel alkalmazása jelentheti a magyarázatot a fenti rejtélyre. A carry trade ügyleteket tipikusan magas tőkeáttétel mellett végzik, és tanulmányunkban bemutatjuk, hogy bár a tőkeáttétel emelheti a hozamokat, egyidejüleg nagymértékben növeli a kockázatot is. Véleményünk szerint a devizapiaci hatékonyatlanság a tőkeáttétel megválasztott mértékéhez kapcsolódik.

Tárgyszavak: Bootstrap, devizapiac, diverzifikáció, tőkeáttétel, fedezetlen kamatparitás

JEL: C32, F31, G11, G15 


\section{INTRODUCTION}

According to the hypothesis of uncovered interest rate parity (UIP), which is a key assumption behind most exchange rate theories, the interest spread between two currencies corresponds to the expected change in the exchange rate. Empirical studies document the rejection of UIP: the currencies of countries whose interest rates are higher tend to appreciate. The investment strategy exploiting this simple observation is called "carry trade": currencies with the higher interest rate are purchased against currencies with the lower interest rate.

Hundreds if not thousands of papers studied the failure of UIP. Farhi and Gabaix (2008) present a comprehensive survey of the more recent literature and also propose a new solution based on a model in which rare worldwide disasters can occur and affect each country's productivity. Carry trade, which is the other side of the coin, has been frequently discussed by the financial press, but also some papers in the academic literature have pointed out that carry trade positions yield profits when maintained over long periods (e.g., Thomas 1986; Burnside, Eichenbaum and Rebelo 2007; Dunis and Miao 2007; Pukthuanthong, Thomas and Bazan 2007; Villanueva 2007; Brunnermeier, Nagel and Pedersen 2008; Burnside, Eichenbaum, Kleshchelski and Rebelo 2008, Jurek, 2008). ${ }^{1}$ Most of these studies have examined the strategy without leverage.

The presence of positive carry trade returns is a puzzle. ${ }^{2}$ One possible solution to the puzzle is that positive return is a compensation of risk, as argued, for example, by Lustig, Roussanov and Verdelhan (2008). Also, by studying the measured skewness of (nonleveraged) carry trade returns Brunnermeier et al. (2008) claim that currency crash risk caused by sudden unwinding of carry trades may discourage speculators from taking on large enough positions to enforce UIP. However, the economic interpretation whether the measured skewness is "large enough" is not without disagreement. For instance, even the maximum of the skewness statistics reported by Brunnermeier et al. (2008) is quite similar

\footnotetext{
${ }^{1}$ Plantin and Shin (2008) build a theoretical model assuming that exchange rates are sensitive to the underlying flow of funds into or out of a currency, and that there is a long term fundamental anchor that prevents exchange rates being completely decoupled from economic fundamentals. Funding externalities induced by the introduction of uncertainty in the evolution of fundamentals lead to an equilibrium in which extended periods of slow appreciations of the high interest rate currency are stochastically interrupted by endogenous crashes.

${ }^{2}$ We study carry trade in this paper, but our answer to the puzzling presence of positive returns may well apply to any other currency strategy that is concluded with leverage, such as technical trading rules.
} 
to the values reported by Burnside et al. (2007), who judged this magnitude to be small. Furthermore, by studying hedged versions of carry trade in which exposure to crashes has been hedged by combining positions in currencies and currency options Burnside et al. (2008) and Jurek (2008) demonstrate that payoff to the carry trade remain positive and statistically significant. Villanueva (2007) also argued that high Sharpe ratios of carry trade were not merely a compensation of risk.

Carry trade transactions are typically concluded with leverage, although no data is available on the extent of leverage carry trade investors might apply, partly because of the lack of comprehensive data for derivatives (Becker and Clifton 2007; Gagnon and Chaboud 2007; Galati, Heath and McGuire 2007; Hattori and Shin 2007)3. These papers also warn that leverage may increase risk. With leveraged positions all or most of the wealth can be lost within a single day. If the strategy survived - but assumed a significant loss - then even later high percentage returns can not add much to the cumulative return, because these high returns are realized on a small fraction of the initial investment. Hence, it is surprising that papers quantifying carry trade payoffs and risks typically studied non-leveraged strategies. In particular, we do not know any paper that studied downside risk of leveraged carry trade positions.

The primary aim of our paper is studying the effects of leverage on forward carry trade positions. 4 While doing that we also contribute to the literature by the following ways. First, we use each of the eleven major currencies as the base currency (against which all other currencies are traded). Existing papers have used only one base currency (either the US dollar or the British pound). When UIP fails, selection of the base currency might matter. 5 Second, similarly to Villanueva (2007) we investigate whether returns are significant with a bootstrap test. Most of the existing papers have documented positive returns for some currency pairs, but they have not tested their significance. Third, our study considers

3 These papers also employed several datasets in search for evidence on the importance of carry trade activity.

4 Any 'classical carry trade', i.e. borrowing a currency with low interest rate and lending one with high interest rate, also leads to leverage. However, concluding transactions on the forward (or futures) market is simple, flexible, incurs low transaction costs and is available for the general public.

5 For example, suppose that a researcher examines 10 currencies and finds that any combinations of them behave according to UIP: the actual return to carry trade based on any of the ten currencies will not be significantly different from zero. Suppose that an eleventh currency is added which is found to move opposite to the prediction of UIP. Using this eleventh currency as the base currency, carry trade will (likely) deliver significant profit against all other currencies, but one can not obviously say that carry trade behavior is a general characteristic of all eleven currencies in the sample. 
transaction costs with the highest possible degree of accuracy; other papers on this subject have made simplifications or simply ignored them. Fourth, we consider the strategies on the basis of daily data and also study the influence of margin requirements that crucially effect leveraged positions. Finally, our work uses a rather long sample period starting in January 1976 and ending in April 2008 for all eleven currencies considered. Some of the currencies we study had floating exchange rates during the full period, while some others were forced out from exchange rate pegs by exchange rate crises which are also included in our sample period. Hence, our results are likely not affected by the peso problem.

To preamble our results we can say that selection of the base currency matters somewhat. The US dollar proved to be the main carry trade currency in the sense that the US dollar based carry trade portfolio including the ten other currencies in equal weights lead to the highest excess return (over the risk free interest rate) and Sharpe ratio, and it also proved to be the most resistant to the shock-amplifying effects of leverage. However, when there is no leverage practically all individual currency pairs lead to positive excess returns. Positive excess returns characterize our full sample period covering more than three decades and hence carry trade profits are not a recent phenomenon on the one hand, and they also have not declined recently on the other hand.

The presence of leverage materially deteriorates the relationship of returns and risks for all currency pairs and portfolios: the Sharpe ratio and skewness are a decreasing function of leverage. We also point out the advantages of diversification: leveraged carry trade portfolios typically lead to much higher returns and Sharpe ratios than individual currencies. With standard leverage levels probably applied by many practitioners nearly all the carry trade positions in a single currency pair would have gone bankrupt or lost the majority of initial investment value. Some portfolios, most notably the US dollar based portfolio, would have survived our 32-year long sample period even with high levels of leverage. However, full period survival came with a very high volatility of monthly returns. Due to psychological factors it is hard to assume that any investor is capable of sticking consistently to a single strategy if he witnesses the loss of, say, 75 percent of its wealth within a short period of time.

Consequently, we argue that although there seem to be significantly positive excess returns to carry trade when there is no leverage and hence there is a strong case against UIP, the significance of returns disappears when leverage is at non-negligible levels. We therefore argue for a special form of inefficiency. If we assume that carry trade transactions are concluded with non-negligible levels of leverage, then the markets seem to be only partly efficient because Sharpe ratios are close to zero in this case. The inefficiency depends on the selection of the level of leverage, since without or with low levels of leverage the simple buyand-hold carry trade positions proved to offer significantly positive excess returns in our 
sample period. Study of the motivations behind the adoption of non-negligible levels of leverage is beyond the scope of our paper.

The rest of the paper is organized as follows. Section 2 describes UIP and the carry trade strategy we employ. Section 3 explains the methodology of evaluating the strategy, namely the methods for the inclusion of transaction costs, the daily evaluation of positions, portfolio management and the bootstrap test. Section 4 describes the data. The empirical results are presented in Section 5 , in which we first study non-leveraged carry trade positions and then turn to the analysis of the effects of leverage. Section 6 concludes.

\section{UNCOVERED INTEREST RATE PARITY AND THE CARRY TRADE STRATEGY}

In foreign exchange markets, the first currency quoted in a currency pair is called the base currency and the second currency is usually named the counter currency. Exchange rates are quoted in per unit of the base currency. ${ }^{6}$ The base currency is also typically considered the accounting currency and we also set the notional amount of the transactions in the base currency. We denote the spot and forward bid and ask rates for the counter currency as $S_{t}^{(b)}$, $S_{t}^{(a)}, F_{t}^{(b)}$ and $F_{t}^{(a)}$. Their averages, called the mid rates, are denoted (without any superscript) as $S_{t}$ and $F_{t}$, respectively. In this paper we use primarily monthly data7 and forward rates with one month maturity.

The hypothesis of UIP postulates that the expected change in the exchange rate is equivalent to the interest rate differential, which in turn equals the difference between the forward rate and the spot rate when the widely supported covered interest rate parity holds (Sarno and Taylor, 2002). The hypothesis is mostly tested with the classic Fama (1984) regression,

$$
\Delta s_{t+1}=\alpha+\beta\left(f_{t}-s_{t}\right)+\varepsilon_{t+1},
$$

where $s_{t}$ and $f_{t}$ are the natural logarithm of $S_{t}$ and $F_{t}$, respectively, the expectation error $\varepsilon_{t+1}$ should be uncorrelated with information available at time t, and $\alpha$ and $\beta$ are the parameters to be estimated. The estimate of $\beta$ should not be significantly different from one if UIP holds, and the estimate of $\alpha$ should be zero when there is no risk premium.

\footnotetext{
${ }^{6}$ For example an exchange rate of 120 Japanese yen to the United States dollar means that JPY 120 is worth the same as USD 1; in this case, the US dollar is the base currency and the Japanese yen is the counter currency.

7 Daily data will be used for calculating the mark-to-market value of open positions.
} 
When UIP holds, the expected return to carry trade is zero when there are no transaction costs and negative when transaction costs are considered. When UIP fails ${ }^{8}$, carry trade may or may not be profitable. The simplest carry trade strategy that was adopted by most papers studying carry trade and that we also adopt is as follows:

$\left\{\begin{array}{lll}\text { sell counter currency } & \text { if } & S_{t}>F_{t} \\ \text { buy counter currency } & \text { if } & S_{t}<F_{t} \\ \text { no trade } & \text { if } & S_{t}=F_{t}\end{array}\right.$.

We adopt this simple strategy as a passive buy-and-hold strategy to avoid data snooping (White, 2000). The notational amount of the transactions is determined by the desired level of leverage on the one hand, and by day-to-day market conditions and the assumed margin requirement on the other hand. When adverse currency movements necessitate unwinding of some of the positions (see Section 3.2), the direction of trade for the remaining positions will be still determined by (2).

\section{METHODOLOGY}

\subsection{TRANSACTION COSTS AND CALCULATION OF RETURNS}

None of the papers studying carry trade listed in our reference list considered transaction costs accurately but they all made some simplifications or simply ignored transaction costs. Most papers considering transaction costs simply assumed that transaction costs are constant and identical for all exchange rates they study. However, transactions costs vary across currency pairs and time as well. Furthermore, none of the papers made a distinction between new and rolled over positions. However, since interest rate differentials are persistent and rarely change sign carry trade positions are mostly rolled over. For example, interest rates used to be higher in New Zealand than in Japan implying that a carry trade strategy for the NZDJPY rate meant buying the New Zealand dollar and selling the yen for many years. On forward currency markets the transaction costs of a rolled over position is much smaller that that of a new position: we found in our database that the transaction costs of a rolled over position typically amount to only 10-20 percent of the transaction costs of a corresponding new transaction (see the Appendix). Consequently, the correct way to

\footnotetext{
8 UIP is typically rejected; see Sarno and Taylor (2002). In addition to the failure of UIP, carry trade may also be motivated by the random walk behavior of nominal exchange rates, which was indeed the starting point of the seminal work of Thomas (1986). See Belaire-Franch and Opong (2005) and Yang, Su and Kolari (2008) for some recent tests of random walk behavior.
} 
calculate the cumulative returns to carry trade is a trading simulation in which a distinction is always made between a new transaction and a transaction rolled over. Monthly returns can be calculated as the growth rate of the cumulative returns.

When the notional amount of the transactions is set in the base currency, the return (in the counter currency) is determined by the following formulae:

$$
\begin{aligned}
& R_{t}=R_{t}^{(\text {new })}+R_{t}^{(\text {rol })} \\
& \begin{cases}\text { if counter currency purchase : } & \left\{\begin{array}{l}
R_{t}^{(\text {new })}=A_{t-1}^{(\text {new })} \cdot\left(S_{t}^{(b)}-F_{t-1}^{(a)}\right) \\
R_{t}^{(\text {rol })}=A_{t-1}^{(\text {rol })} \cdot\left(S_{t}^{(b)}-\left[S_{t-1}^{(b)}+\left(F_{t-1}^{(a)}-S_{t-1}^{(a)}\right)\right]\right)
\end{array}\right. \\
\text { if counter currency sale : } & \left\{\begin{array}{l}
R_{t}^{(\text {new })}=A_{t-1}^{(\text {new })} \cdot\left(-S_{t}^{(a)}+F_{t-1}^{(b)}\right) \\
R_{t}^{(\text {rol })}=A_{t-1}^{(\text {rol })} \cdot\left(-S_{t}^{(a)}+\left[S_{t-1}^{(a)}+\left(F_{t-1}^{(b)}-S_{t-1}^{(b)}\right)\right]\right]
\end{array}\right.\end{cases}
\end{aligned}
$$

where $R_{t}, R_{t}^{(\text {new })}$ and $R_{t}^{(\text {rol) }}$ are the return (profit if positive, loss if negative) measured in the counter currency realized on the total, new, and rolled-over positions respectively, whereas $A_{t}^{(\text {new })}$ and $A_{t}^{(\text {rol })}$ are the notional amounts of the new or rolled-over contracts measured in the base currency. The return converted into the base currency is:

$$
P_{t}=\left\{\begin{array}{lll}
\frac{R_{t}}{S_{t}^{(a)}} & \text { if } & R_{t}>0 \\
\frac{R_{t}}{S_{t}^{(b)}} & \text { if } & R_{t}<0
\end{array},\right.
$$

where $P_{t}$ is the return converted into the base currency. Obviously, when there is no trade then $R_{t}=R_{t}^{(\text {new })}=R_{t}^{(\text {rol })}=P_{t}=0$.

The total return to a carry trade investment comprises two factors: the payoffs of the forward transaction itself and the interest income of collateral. Total return is comparable to returns to other investments (e.g. equities) and is calculated for example by Burnside et al. (2007, 2008), while the payoff of the forward transaction itself can be regarded as the excess return over the risk free interest rate as calculated for example by Thomas (1986) and Pukthuanthong et al. (2007). Throughout the paper we do not add the interest income of collateral and hence when we claim that return to carry trade is significant, it means that the excess return over the risk free interest rate is significant. 


\subsection{DAILY EVALUATION OF THE POSITIONS}

In our calculations we assume that the investor determines the direction of trade, opens and rolls over forward positions only on the last weekday of each month for the last weekday of the following month. Positions can also be closed partly (if a loss was assumed) or fully (if the direction of trade has changed) on the last weekday of month if directed by the trading simulation. Consequently, the desired level leverage is not reached on a daily basis, but only on the last weekday of the month.

It often occurs in practice that during the month extreme changes in the exchange rates emerge, and then they are partly corrected by the end of the month. Hence, it is not unlikely that the loss on certain open positions hits such a value during the month that in reality would have led to forced liquidation, i.e. obligate and ultimate closing of some of the positions (with a loss). For this reason, the mark-to-market value of open positions is evaluated on a daily basis.

In practice, the investor having leveraged positions receives a margin call if losses on open positions deplete part of the collateral and the investor has the chance to deposit new funds. If new funds are deposited, it implies that the investor kept liquid assets somewhere else and hence the effective leverage he/she applied was smaller. We abstract from margin calls but study various leverage values between 1 and 25 .

Daily evaluations require forward rates for the last weekday of the month, which are not readily available. To approximate these rates, we assumed that both the bid and ask swap points linearly grow in time from zero to the swap points included in the monthly forward rate, which allows us to calculate the bid and ask forward rate for the last day of the month for all days in our sample.

With the use of the daily forward rates referring for the last day of the month the open positions are evaluated in each day. The worth of open positions is called 'mark-to-market value', that is, this is the profit (or loss) to be realized if the position would be closed. We define the net worth of the investment as the sum of the total worth of the investment at the end of the previous month, the mark-to-market value of open positions, and the (possible) losses on positions that have already been closed in the given month. If the net worth of the investment is less than the amount needed for margin requirements then the notional amount of open positions is reduced, i.e. some of the open positions are ultimately closed with an assumed loss. This partial closing during the month is called forced liquidation. The amount of forced liquidation is such that after that the net worth of the investment be equal to the required margin. Obviously, we evaluate the positions every weekday of the month and 
impose forced liquidation on any day when needed. If the net worth of the investment turns to negative on a given day, the investment is regarded as bankrupted.

\subsection{PORTFOLIO MANAGEMENT}

DeMiguel, Garlappi and Uppal (2007) compare the naive equally weighted portfolio with various optimizing strategies. Of the 14 models they evaluate across seven empirical datasets, none was consistently better than the equally weighted portfolio in terms of Sharpe ratio, certainty-equivalent return, or turnover. This indicates that, out of sample, the gain from optimal diversification is more than offset by estimation error. For this reason, in our paper we do not even attempt to determine optimal weights, but the currencies are included with equal weights in all portfolios.

Our calculations implement this approach with the assumption that on the last day of each month the same amount (measured in the base currency) of positions are opened (or rolled over) for each of the 10 counter currencies in the portfolio. In other words, at the end of the month an amount corresponding to the 1/10 part of the existing wealth multiplied by the rate of leverage is open for each currency. If within the month any forced liquidation occurs, the open notional amount of each currency is reduced by the $1 / 10$ part of the amount to be closed, irrespective of the fact which currency/currencies generated the loss within the month.

\subsection{HYPOTHESIS TEST}

Following the procedures described so far, the return to carry trade can be calculated. However, the distribution of any measure of return is not known and its derivation is certainly complicated by the fact that exchange rate changes, and hence monthly returns to carry trade, have skewed and leptokurtotic distributions. For this reason, we adopt a bootstrap test similarly to Villanueva (2007) to derive the distribution of any measure of carry trade returns.

The expected return to carry trade is zero when UIP holds and there are no transaction costs. Hence, we impose UIP in the bootstrap data generating process (DGP). We need a second behavioral equation in order to be able to bootstrap both spot and forward rates and a rather convenient choice is to assume that the interest rate differential follows a first order autoregressive process. Hence, for a given currency pair the bootstrap DGP is:

$$
\begin{aligned}
& \Delta s_{t+1}=f_{t}-s_{t}+u_{t+1}, \\
& \left(f_{t+1}-s_{t+1}\right)=\gamma_{0}+\gamma_{1}\left(f_{t}-s_{t}\right)+v_{t+1},
\end{aligned}
$$


where $u_{t}$ and $v_{t}$ are innovations and $\gamma_{0}$ and $\gamma_{1}$ are parameters. Since we also aim to investigate the significance of the returns of a portfolio including ten currencies against the base currency under study, we stack equations (5) and (6) for all ten currencies to arrive at a model having 20 equations and estimate the model with OLS. In each bootstrap iteration we draw simultaneously from the residuals of the 20 equations to preserve the correlation structure of currency movements and interest rate differentials. 9 We bootstrap the log exchange rates and obviously $S_{t}=\exp \left(s_{t}\right)$ and $F_{t}=\exp \left(f_{t}\right)$, which will be needed for trading rule simulations.

We set the initial conditions, $s_{0}$ and $f_{0}$, equal to the first observation of the actual sample, generate 1000 bootstrapped series for the same number of observations as in the data and calculate returns to carry trade the same way as for the actual data to approximate the distribution of returns under the null hypothesis of no excess return. We perform a one sided hypothesis test with the alternative that carry trade is profitable. We test this hypothesis when transaction costs are not considered, which is a test for UIP, and also when transaction costs are considered, which is a test whether the failure of UIP can be exploited to make profit. Note that in this later case the bootstrap distribution of the test statistic simulated under no transaction costs is used. This is because we are interested in whether returns to carry trade are significantly larger than zero when transaction costs are considered. Under the null hypothesis of UIP, the expected return to carry trade is negative when transaction costs are considered, and it is not an interesting question whether actual returns are larger than their negative expected value. When transaction costs are not considered, all exchange rates in equations (3) and (4) are mid rates (instead of bid and ask rates) and hence calculations are simpler.

\section{DATA}

The sample period includes data between January 1976 and April 2008 for all possible pairs of the eleven major currencies: Australian dollar (AUD), British pound (GBP), Canadian dollar (CAD), Danish krone (DKK), German mark (DEM), Japanese yen (JPY), New Zealand dollar (NZD), Norwegian krone (NOK), Swedish krona (SEK), Swiss franc (CHF) and US dollar (USD). The euro (EUR) is treated as the successor currency of the German mark. Our primary frequency is monthly by taking the last weekday of the month, which is used for determining the direction of carry trade, opening, rolling over and closing positions. We also use daily data for evaluating the mark-to-market value of open positions and to implement

\footnotetext{
9 In addition to this i.i.d. bootstrap, Villanueva (2007) also employed block bootstraps for the currencies he studied. The p-values from the i.i.d. and block bootstraps were almost identical.
} 
forced liquidation when needed. Bid and ask spot and forward exchange rates against the US dollar are available since October 1983 for CHF, DEM, JPY and December 1984 for the other seven currencies; euro rates are available since 1999 and British pound rates are generally available since 1976, with the exceptions of the JPY (forward rates are available since August 1978) and AUD and NZD (spot bid/ask rates are available since July 1990 and forward bid/ask rates are available since December 1996, while spot mid rates are available since 1976). The sample period was extended for these three currencies against the pound with the assumption of covered interest rate parity that allows the calculation of forward mid rates by using interest rates. Bid-ask spreads were added to AUD and NZD for the 1985-1996 period by assuming that spreads are the same as for the USD rates. For the 1976-1984 period in the cases of AUD and NZD and for the 1976-1978 period in the case of the yen bid-ask spreads were assumed to be equal to the average spread in 1985-1989 (AUD and NZD) and 1978-1980 (JPY).

USD rates for 1976-1983/84 were calculated from GBP rates assuming that the spreads are the same in percent. German mark rates for 1976-1998 were calculated from USD rates assuming the spreads are the same in percent, and data have been extended with the data of the euro since 1999. For all other base currencies (CHF, JPY, CAD, AUD, NZD, DKK, NOK, SEK) the mid rates were derived from USD rates and the spreads were derived to be equal to the sum of the larger spread and half of the smaller spread. For instance, if the spread of USDCAD was 0.06 percent and the spread of USDAUD was 0.10 percent then the spread of CADAUD has been set equal to 0.13 percent.

All exchange rate and some of the interest rate series are from Thomson DataStream, while some of the interest rates are from central banks. Daily DataStream data contain a number of erroneous elements. A typical error is that there is no difference between the bid and ask rates, or the spread of the forward exchange rate is smaller than the spread of the spot exchange rate. These cases have been screened for all days and with no other options being available we have replaced them with those values for the preceding day that did not contain such errors. A third likely error is that the spot exchange rate moves but the forward rate stays constant for some days leading to - in some cases - huge jumps in the implied swap point. A similar case is when spot rates are unchanged but forward rates change. These errors have been checked on a daily basis and were corrected by assuming that the swap points stayed constant from the previous day. ${ }^{10}$ Luckily, very few of the erroneous elements

\footnotetext{
10 The first two error types are errors by definition, while these later two ones are only likely errors. For example, it is unlikely that the USDDEM interest rate differential jumped over 60 percent per year on a given day in our sample. To be on the safe side, we adopted four simultaneous conditions to correct these occurrences, namely,
} 
are related to the last weekday of the month which is our primary data frequency. Probably there was a data error in the GBPDEM, GBPCHF, and GBPJPY rates in the seventies and eighties, because their bid-ask spreads were 4-5 times larger than that of other exchange rates (including, for example, GBPDKK, GBPNOK, GBPSEK). Furthermore, the sum of the percentage spread of, say, USDDEM and USDGBP was much less than the percentage spread of GBPDEM. For this reason, GBPDEM, GBPCHF and GBPJPY spreads have been set equal (in percent) to spreads against the USD.

\section{RESULTS}

\subsection{UNCOVERED INTEREST RATE PARITY}

As a startup, we estimated the classic Fama regression shown in equation (1) for all possible currency pairs of our sample. The upper triangular of Table 1 shows $\beta$ parameter estimates and the $\mathrm{p}$-values of the hypothesis test that $\beta=1$ against the one-sided alternative that $\beta<1$, using the bootstrap distribution of the estimated $\beta$ coefficient. Among the 55 currency pairs there are only five which lead to a parameter estimate in excess of one, and many of the parameter estimates are negative. The hypothesis tests indicate that most of the parameter estimates are significantly less than one.

Elements in the lower triangular of Table 1 present the means and standard deviations of the $\beta$ coefficient estimated for the bootstrap samples. The means are fairly close to one indicating that on average the Fama-regression can well capture the true UIP in our bootstrap samples.

\subsection{NON-LEVERAGED CARRY TRADE RETURNS}

When UIP fails, carry trade may or may not offer significantly positive returns both in a statistical and an economic sense. Table 2 shows the cumulative value of an initial 100 nonleveraged carry trade position in the base currency from January 1976 to April 2008 for all currency pairs and portfolios (both with and without transaction costs). Bootstrap p-values of the null hypothesis that there is no excess return against the one-sided alternative that there is, as described in Section 3.4, are also shown. As we have already explained, returns we

that both bid and ask forward rates are unchanged and both bid and ask spot rates are changed when the forward rates were unchanged, and similarly when the spot rates were unchanged. 
calculate are excess returns over the risk-free interest rate because they do not include the interest income of collateral. ${ }^{11}$

When transaction costs are not included, 53 of the 55 currency pairs ended the whole period with positive excess returns and 24 of them proved to be significant at least at a $10 \%$ level according to our bootstrap test. With transaction costs included 47 of the 55 individual currency pairs show positive excess returns and 14 of them are significant.

Irrespective of the base currency, all eleven portfolios lead to positive excess returns both with and without the inclusion of transaction costs. When transaction costs are disregarded these results are significant for ten of the eleven portfolios at most at an $11 \%$ level. The exception is the yen based portfolio, with an excess return larger than that of five other currency based portfolios, but its excess return is significant only at a $17 \%$ level. When transactions costs are considered the actual excess returns are still positive for all eleven portfolios, though only five of them are statistically significant.

The magnitude of excess returns can be generally regarded as large in an economic sense even when transaction costs are considered. For example, the 370.0 cumulative excess return for the US dollar based portfolio showed in Table 2 is equivalent to a 4.1 percent annualized excess return.

Table 3 shows the Sharpe ratio of monthly logarithm excess returns of non-leveraged carry trade positions and the bootstrap p-value of the test that Sharpe ratio is zero against the one-sided alternative that it is positive. The p-values are highly similar to those reported in Table 2 indicating the robustness of our tests to the selection of the measure of returns. Table 4 reports the skewness and kurtosis of logarithm excess returns. In most cases returns are skewed to the left and have high kurtosis. It is evident from this table that transactions costs make returns somewhat more skewed and leptokurtotic.

Tables 2 and 3 also indicate that the selection of the base currency matters somewhat. The US dollar proved to be the main carry trade currency in the sense that the US dollar based carry trade portfolio led to the highest excess return and largest Sharpe ratio.

\footnotetext{
${ }^{11}$ The selection of the base currency in a currency pair matters when transaction costs are considered in trading simulations. This is because in equation (3) the differences between spot and forward rates appear. When we change the roles of base and counter currencies the ask rates will be the reciprocals of bid rates and bid rates will be the reciprocals of ask rates. The differences between these reciprocals will constitute to somewhat different magnitudes (in percent) leading to somewhat different results when the other currency is regarded as base currency. This issue is akin to Siegel's Paradox. We calculated both options for all currency pairs and the differences were tiny. Still, to be on the conservative side, we report the smallest of the two in the lower triangular of Table 2.
} 
Dominance of the USD based portfolio is even stronger when transaction costs are considered. These findings likely reflect the dominant role of the US dollar in currency markets. According to BIS (2007, Tables B5 and B6, p. 10 and 11) the US dollar is involved in 86.3 percent of foreign exchange market turnover in 2007 and its share was even higher in earlier years. The dominant role of the US dollar is also reflected in the fact that transactions costs are generally lower for trades in which the dollar is one of the two currencies.

The time pattern of carry trade returns may be also interesting. Figure 1 plots the time series of cumulative excess returns for all individual currency pairs and portfolios. Although there are many ups and downs, the key message of Figure 1 is the upward trending behavior. The visual impression is that the positive excess returns do not diminish in time.12 It is apparent that the standard deviation of the portfolio returns is smaller than that of the individual currency returns.

When comparing the eleven base currencies, the most variable outcomes are associated with the Japanese yen, Australian dollar and New Zealand dollar leading to small Sharpe ratios. The underlying reasons can probably be explained by the "one-directional" nature of these portfolios. For instance, mostly selling positions of the yen and buying positions of the Australian and New Zealand dollars have been made in most of the sample period. In the portfolios built upon the other base currencies, the purchase and selling positions of the base currencies were more balanced, and thus they potentially mitigated the risks of these portfolios from general movements of the base currency.

To sum up, when there is no leverage, returns to carry trade provide a strong case against UIP. Positive excess returns do not seem to diminish in time and our findings also highlight that carry trade behavior of exchange rates is not a recent phenomenon but a rather general characteristic of major currencies in all of our sample period covering 1976-2008.13 Failure of UIP could have been exploited for making profit especially if the US dollar, the main

12 The cumulative excess return curve of the USD based portfolio flattened out in the final three years of our sample. This was probably the consequence that dollar was weakening ahead of expected FED rate cuts even though the level of interest rates in the US was larger than in some other countries in some part of this period. However, the USD based carry trade portfolio realized huge gains in 2000-2005, and all other portfolios tended to realize excess returns even in the final years of our sample.

13 Our finding that carry trade payoffs did not decline over time could be contrasted with the voluminous literature on technical trading rules. While several authors have concluded that profits to technical trading rules declined recently (see, for example, Olson, 2004), Dueker and Neely (2007) showed that returns to ex ante trading rules derived from Markov-switching models did not decline. 
international currency, is used as the base currency, but excess returns were significant for many other currency pairs and portfolios even if transaction costs are considered.

\subsection{LEVERAGED CARRY TRADE RETURNS}

In forward currency markets transactions are concluded with leverage, because only a small percentage of the notional amount of the transaction (for example, four percent) is required by the financial intermediator to be deposited as collateral for the coverage of potential losses. The investor may deposit any larger amount than minimally required or alternatively may keep some of his/her assets in other liquid instruments ready for covering eventual losses, i.e. the investor may opt for any smaller leverage that would maximally be allowed by the given margin requirement.

In our calculations the profitability of the carry trade strategy is examined along various leverage values as well as various margin requirements. Margin requirements are treated parametrically between zero and ten percent14, whereas leverage is considered between one and twenty-five, or the maximum level allowed by the given margin requirement. For instance, if margin requirement is five percent, the maximum value of the leverage is 20.

The investment is deemed to have gone bankrupt if the worth (i.e. marked to market value) of the investment drops under zero; such a case can not happen when there is no leverage. We found that on several instances the presence of margin requirement and the associated forced partial liquidations of open positions prevented the complete loss of wealth, yet in many cases it is just a seeming result: there are examples when the value of the initial investment of 100 drops below 0.0000001. When the strategy survived, there were generally small differences between the outcomes associated with different assumptions about level of margin requirement. For this reason and also to conserve space we only report results to the case when margin requirement is four percent.15

Figure 2 clearly highlights that the return is an inverted U-shaped function of the leverage: when leverage is small an increase in the leverage raises the return, but over a certain leverage value the return starts to drop. The underlying reason is that when leverage is high, adverse currency movements can lead to losses depleting part or most of the wealth which is deposited as collateral. In these cases yields at later dates are realized on a reduced wealth.

\footnotetext{
14 Margin requirements may vary with the different investors and financial intermediators. For the one month maturity forwards of major currencies, they typically range from 2 to 5 percent.

15 Detailed results for other margin requirements are available from the author upon request.
} 
The benefits of diversification show up clearly from the results.16 For example, the topleft panel of Figure 3 showing US dollar based carry trade returns indicates that with higher leverage rates, the individual currencies would have gone bankrupt, or realized negative yields in contrast to the simple equally weighted portfolio that offered high percentage returns even with a 25 -fold leverage. The portfolio tend to dominate individual currencies in the cases of other base currencies, although these proved to be less resistant to the shock amplifying effect of leverage than the US dollar based portfolio.

It is noteworthy that portfolios based on the Japanese yen, Australian dollar, New Zealand dollar, Norwegian krone and Swedish krona would have bankrupted at higher levels of leverage. The last four of these five currencies had fixed exchange rate systems in the early part of our sample and the bankruptcy dates are related to large devaluations of the exchange rates. The yen based portfolio bankrupted in October 1998 when the yen strengthened about 15 percent in a week. It's also noteworthy that although the British pound was forced out from the ERM in 1992, the pound based portfolio also proved to be reasonably resistant to the increase in leverage.

Regarding the Sharpe ratio, the striking observation is that it decreases with the increase in leverage (Figure 3). Despite the finding that an increase in the leverage raises the return when leverage is small for most currency pairs and portfolios, the Sharpe ratio almost monotonously decreases with the increase of the leverage at any level of leverage for all individual currency pairs and portfolios. This indicates that leverage substantially increases volatility.

The benefits of diversification also clearly show up when considering Sharpe ratios. For example, although the USDDKK individual currency pair had larger returns than the US dollar based portfolio when leverage was below 9, the portfolio had higher Sharpe ratio (topleft panel of Figure 3). For other base currencies the portfolios likewise tend perform much better than individual currencies in terms of the Sharpe ratio.

Figure 4 indicates that skewness also tend to fall with the increase of the leverage. For example, the skewness of the US dollar based portfolio is -0.87 when there is not leverage. When leverage is 10 , the skewness is -2.14 , and when leverage is 25 , the skewness is -3.88 . Consequently, downside risk is materially amplified by leverage. Parallel with the fall in skewness, kurtosis increases (Figure 5).

It is also instructive to look at the time plot of monthly returns. Due to space limitations Figure 6 shows the returns only for one individual currency pair and one portfolio. We

16 See Driessen and Laeven (2007) for a comprehensive analysis of benefits to international portfolio diversification. 
selected the USDDKK currency pair and the US dollar based portfolio, because these led to the highest return and Sharpe ratio when there is no leverage. Figure 5 indicates that large percentage losses are not irregular when leverage is high.

Another measure of downside risk is maximum loss. Table 5 indicates that the maximum loss increases with the increase in leverage both for the USDDKK currency pair and the USDbased portfolio. For instance, with a 15-fold leverage, there was a month (March 1991) when a USD-based portfolio carry trade investor would have lost 74.2 percent of his wealth.

\section{CONCLUSION}

Studying all the possible pairs of eleven major currencies from 1976 to 2008 we have documented that holding carry trade positions consistently throughout this period would have resulted in positive excess returns for nearly all the individual currencies and all portfolios if the strategy had been implemented without any leverage. Returns to carry trade do not diminish in time which is a puzzle.

The carry trade strategy is typically implemented with leverage and the characteristics of leveraged returns could be dramatically different from that of non-leveraged returns. It is possible that with a leveraged position the investor loses all of his collateral in 'bad times', or suffers such serious losses that later on the cumulative value of the investment cannot be significantly increased even by high percentage returns.

We have shown that carry trade returns are an inverted U-shaped function of the leverage and an increase in the leverage decreases the Sharpe ratio and skewness. Even if there is some debate in the literature whether non-leveraged skewness is large in economic terms or not, the skewness of leveraged carry trade returns are much larger (in absolute terms) than skewness of non-leveraged returns. According to our calculations, the carry trade strategy designed for individual currencies (with just a few exceptions) would have gone bankrupt, or lost the majority of wealth with higher levels of leverage. Skewness and Sharpe ratios also fall with the increase in leverage for portfolios of currencies, but we have also found that the application of a portfolio carries considerable diversification advantages and ex post returns can be extremely high. For instance, if an investor adopted a 15-fold leverage for a US dollar based portfolio including the ten other major currencies as counter currencies and faced a four percent margin requirement, then a simple 'buy and hold and close your eyes' carry trade strategy would have ended with a 46.0 percent annualized excess return over the risk free interest rate. To put it in other worlds, a USD 1 investment in January 1976 into a carry trade portfolio with 15-fold leverage would have grown to USD 198032 by April 2008 considering transaction costs but not the interest income of collateral. Yet, these extremely high returns would have been accompanied by exceptionally high volatility and it is unlikely 
that investors can close their eyes and stick to an investment strategy when they face a substantial loss in a short period of time.

We did not aim to answer the question why investors apply leverage when pursuing carry trade transactions, but have shown that although unleveraged carry trade positions yield significantly positive excess returns and hence there is a strong case against UIP, the significance of returns disappears when leverage is at non-negligible levels. Consequently, we argue for a special form of inefficiency related to the level of leverage. If our conjecture that carry trade investors apply non-negligible levels of leverage is right, markets are partly efficient because Sharpe ratios are close to zero in this case, but partly inefficient because with no or low levels of leverage Sharpe ratios tended to be significantly positive in our sample. A natural extension of our work would be the development of a procedure determining optimal leverage for carry trade, which could be the scope of further research. 


\section{APPENDIX: TRANSACTION COSTS}

\section{A.1. DEFINITION OF TRANSACTION COSTS OF A FORWARD CURRENCY TRANSACTION}

In a forward currency contract transaction costs are incurred by the presence of bid-ask spreads. The investor faces bid-ask spreads in both the spot and forward markets. The wider spread of forward prices is due to the additional bid-ask spread of the swap points.

In the case of no transaction costs, all the transactions would be concluded at middle rates. The following example illustrates the definition of transaction costs on the basis of hypothetical values of the USDJPY rate. Let us assume that the rates indicated in the table below are actually effective for the conclusion of the transaction, and by the time of the closing of the transaction they are still unchanged:

Table A.1

\section{Hypothetical USDJ PY exchange rates for Appendix A.1}

\begin{tabular}{|l|r|r|r|}
\hline & \multicolumn{1}{|c|}{ BID } & \multicolumn{1}{c|}{ MID } & \multicolumn{1}{c|}{ ASK } \\
\hline Spot exchange rate & 120.00 & 120.02 & 120.04 \\
\hline Swap points & -1.01 & -1.00 & -0.99 \\
\hline Forward exchange rate & 118.99 & 119.02 & 119.05 \\
\hline
\end{tabular}

If there were no transaction costs the investor could purchase the US dollar at a forward rate of 119.02, and then upon maturity the transaction would be closed at a rate of 120.02. In the case of bid-ask spreads, the investor can buy US dollar at a 199.05 rate, which means that upon the opening of the transaction the investor in fact "pays" half of the spread of the spot market and the half of the spread of the swap points. At the time of the closing of the transaction, the investor faces a 120.00 rate, i.e. "pays" the other half of the spread of the spot market. Thus, on the aggregate with the opening and closing of the new transaction the entire spread of the spot exchange rate and the half of the spread of the swap points are to be paid as transaction costs. If the transaction is not closed ultimately, but rolled over, the spread of the spot market need not be paid again, but only the half of the spread of the swap points. 17

17 When a position is rolled over, it is not absolutely necessary to settle the bid and ask spread of the spot currency market at the end of the first period, but it is also possible to roll the contract over at any spot rate between the prevailing spot market bid and ask rates on the basis of the swap points, and the spot market spread that has not been settled so far is to be settled only in the last period, when the transaction is closed 


\section{A.2. A NUMERICAL EXAMPLE FOR THE RECOGNITION OF TRANSACTION COSTS}

The following numerical example illustrates the procedure for the recognition of transaction costs on the basis of hypothetical values of the USDJPY rate provided that the investor concludes a carry trade transaction (buying USD and selling JPY). The following table shows the hypothetical rates for four consecutive periods:

Table A.2

Hypothetical USDJ PY exchange rates for Appendix A.2

\begin{tabular}{|l|l|l|l|l|}
\hline & SPOT BID & SPOT ASK & FWD BID & FWD ASK \\
\hline 1. & 116.00 & 116.03 & 115.00 & 115.04 \\
\hline 2. & 118.00 & 118.03 & 117.00 & 117.04 \\
\hline 3. & 120.00 & 120.03 & 119.00 & 119.04 \\
\hline 4. & 118.50 & 118.53 & 117.50 & 117.54 \\
\hline
\end{tabular}

\section{Period 1}

In Period 1, the investor buys the dollar and sells the yen with a notional amount of, say, USD 100 at the prevailing forward ask rate of 115.04 .

\section{Period 2}

By Period 2, the US dollar has strengthened, which, coupled with the earnings associated with the interest date differential ("the carry") the investor could realize profit which is equal to $100 *(118.00-115.04)=296$ yen. This profit is converted into US dollar in the spot market (with the use of the spot ask rate): 296/118.03 $=2.507837$ US dollars. He does not close the forward position, but rolls it over, meaning that contracts for USD 100 are concluded at a rate of $118.00+(117.04-118.03)=117.01$ for the following month. However, the USD 2.507837 profit can be contracted only at a forward rate of 117.04 .

ultimately. In order to simplify our calculations, we have assumed in equation (3) of the main text that the entire spot market spread is settled in the first period. 


\section{Period 3}

By Period 3, the US dollar has strengthened again; therefore the investor has repeatedly witnessed the realization of profits. The profit realized on the transaction involving the forward rate of 117.01: 100*(120.00-117.01) = 299 yen, and equivalent of 299/120.03 = 2.491044 US dollar. On the other hand, the profit of the transaction involving USD 2.5078372 and launched in Period 2 is $2.507837^{*}(120.00-117.04)=7.423197$ yen, i.e. $7.423197 / 120.03=0.061845$ US dollar. Consequently, the aggregate amount of new profit generated in Period 3 is $2.491044+0.061845=2.552888$ US dollar, which the investor can contract at a rate of $\mathbf{1 1 9 . 0 4}$ for the following month. The contract rolled over equals to $100+2.507837=102.507837$ US dollar, which can be rolled over again at a rate of $120.00+(119.04-120.03)=119.01$.

\section{Period 4}

By period 4, the US dollar has weakened. The result of the investor on the rolled-over USD 102.507837 is $102.507837^{*}(118.50-119.01)=-52.278997$ yen, an equivalent of $-52.278997 / 118.50=-0.441173$ US dollar (due to the loss, he sells US dollar and buys yen in the spot market, and therefore the spot bid rate is valid). The result realized on the USD 2.552888 position opened in Period 3: $2.552888^{*}(118.50-119.04)=-1.378560$ yen, that is $-1.378560 / 118.50=-0.011633$ US dollar. The aggregate result in Period 4 will then be $-0.441173-0.011633=-0.452806$ US dollar. As it has been mentioned above, the investor had to purchase yen to settle this loss, and therefore can roll over the amount without this loss, i.e. the amount rolled over is $102.507837+2.552888-0.452806=104.607919$ US dollar. This amount can be rolled over for the following period at a rate of $118.50+(117.54-118.53)=$ 117.51. Since the investor has had no profit, no new contract has been concluded in this period.

The results of USD selling positions (if the US dollar offers lower interest rates than the counter currency) can be calculated in a manner that is similar to the methodology presented in the calculation example. In these cases, the reverses of all the bid-ask rates indicated in the calculation example are to be used, except for the one applied to the conversion of the result to US dollar where the use of bid or ask rates always depends on the fact whether the position has been profitable (the investor buys US dollar) or loss-making (the investor sells US dollar). 
Table A.3.1

Transaction costs of US dollar rates

\begin{tabular}{|c|c|c|c|c|c|c|c|}
\hline \multirow[b]{2}{*}{$\begin{array}{c}\text { Currency } \\
\text { pair }\end{array}$} & \multirow[b]{2}{*}{ period } & (1) & (2) & $(3)=(2)-(1)$ & $(4)=1 / 2 *(3)$ & $(5)=(1)+(4)$ & $(6)=(4) /(5)$ \\
\hline & & $\begin{array}{l}\text { Spread of } \\
\text { spot } \\
\text { exchange } \\
\text { rate }\end{array}$ & $\begin{array}{l}\text { Spread of 1- } \\
\text { month } \\
\text { forward } \\
\text { exchange } \\
\text { rate }\end{array}$ & $\begin{array}{l}\text { Forward } \\
\text { spread due } \\
\text { to swap } \\
\text { points }\end{array}$ & $\begin{array}{l}\text { 1/2-times } \\
\text { the previous } \\
\text { column: } \\
\text { transaction } \\
\text { cost of a } \\
\text { roll-over } \\
\text { position }\end{array}$ & $\begin{array}{l}\text { Transaction } \\
\text { cost of a } \\
\text { new position }\end{array}$ & $\begin{array}{l}\text { Transaction } \\
\text { cost of a } \\
\text { roll-over } \\
\text { position in } \\
\text { percent of } \\
\text { transaction } \\
\text { cost of a } \\
\text { new position }\end{array}$ \\
\hline \multirow[t]{3}{*}{ USDGBP } & $1985-1991$ & 0.092 & 0.117 & 0.025 & 0.013 & 0.105 & $12 \%$ \\
\hline & 1992-1998 & 0.067 & 0.080 & 0.013 & 0.006 & 0.074 & $9 \%$ \\
\hline & 1999-2008 & 0.041 & 0.054 & 0.014 & 0.007 & 0.048 & $14 \%$ \\
\hline \multirow[t]{3}{*}{ USDDEM } & $1985-1991$ & 0.070 & 0.084 & 0.014 & 0.007 & 0.077 & $9 \%$ \\
\hline & 1992-1998 & 0.065 & 0.076 & 0.010 & 0.005 & 0.070 & $7 \%$ \\
\hline & 1999-2008 & 0.045 & 0.061 & 0.016 & 0.008 & 0.053 & $15 \%$ \\
\hline \multirow[t]{3}{*}{ USDJPY } & 1985-1991 & 0.076 & 0.097 & 0.021 & 0.010 & 0.087 & $12 \%$ \\
\hline & 1992-1998 & 0.086 & 0.099 & 0.013 & 0.007 & 0.093 & $7 \%$ \\
\hline & 1999-2008 & 0.061 & 0.098 & 0.037 & 0.018 & 0.080 & $23 \%$ \\
\hline \multirow[t]{3}{*}{ USDCHF } & $1985-1991$ & 0.107 & 0.130 & 0.024 & 0.012 & 0.119 & $10 \%$ \\
\hline & 1992-1998 & 0.077 & 0.098 & 0.021 & 0.010 & 0.087 & $12 \%$ \\
\hline & $1999-2008$ & 0.050 & 0.090 & 0.040 & 0.020 & 0.070 & $28 \%$ \\
\hline \multirow[t]{3}{*}{ USDCAD } & 1985-1991 & 0.079 & 0.106 & 0.027 & 0.014 & 0.092 & $15 \%$ \\
\hline & 1992-1998 & 0.064 & 0.083 & 0.018 & 0.009 & 0.074 & $12 \%$ \\
\hline & $1999-2008$ & 0.053 & 0.078 & 0.025 & 0.012 & 0.065 & $19 \%$ \\
\hline \multirow[t]{3}{*}{ USDAUD } & $1985-1991$ & 0.138 & 0.185 & 0.046 & 0.023 & 0.161 & $14 \%$ \\
\hline & 1992-1998 & 0.121 & 0.163 & 0.042 & 0.021 & 0.142 & $15 \%$ \\
\hline & 1999-2008 & 0.098 & 0.142 & 0.044 & 0.022 & 0.120 & $18 \%$ \\
\hline \multirow[t]{3}{*}{ USDNZD } & 1985-1991 & 0.299 & 0.452 & 0.153 & 0.077 & 0.376 & $20 \%$ \\
\hline & 1992-1998 & 0.168 & 0.209 & 0.041 & 0.021 & 0.189 & $11 \%$ \\
\hline & 1999-2008 & 0.129 & 0.189 & 0.060 & 0.030 & 0.159 & $19 \%$ \\
\hline \multirow[t]{3}{*}{ USDDKK } & $1985-1991$ & 0.095 & 0.159 & 0.064 & 0.032 & 0.127 & $25 \%$ \\
\hline & 1992-1998 & 0.103 & 0.192 & 0.089 & 0.044 & 0.148 & $30 \%$ \\
\hline & 1999-2008 & 0.053 & 0.144 & 0.092 & 0.046 & 0.099 & $47 \%$ \\
\hline \multirow[t]{3}{*}{ USDSEK } & $1985-1991$ & 0.108 & 0.150 & 0.042 & 0.021 & 0.129 & $16 \%$ \\
\hline & 1992-1998 & 0.135 & 0.183 & 0.047 & 0.024 & 0.159 & $15 \%$ \\
\hline & 1999-2008 & 0.087 & 0.147 & 0.060 & 0.030 & 0.117 & $26 \%$ \\
\hline \multirow[t]{3}{*}{ USDNOK } & $1985-1991$ & 0.102 & 0.154 & 0.052 & 0.026 & 0.128 & $20 \%$ \\
\hline & 1992-1998 & 0.088 & 0.157 & 0.069 & 0.034 & 0.123 & $28 \%$ \\
\hline & 1999-2008 & 0.049 & 0.147 & 0.098 & 0.049 & 0.098 & $50 \%$ \\
\hline
\end{tabular}

Note. Values shown in the first two data columns correspond to $100 \cdot \ln \left(\mathrm{S}_{\mathrm{t}}^{\mathrm{a}} / \mathrm{S}_{\mathrm{t}}^{\mathrm{b}}\right)$ and $100 \cdot \ln \left(F_{t} a / F_{t} b\right)$, respectively. See section 3.1 of the main text and Appendix A.1 for the definition and interpretation of transaction costs. 
Table A.3.2

Transaction costs of GBP rates

\begin{tabular}{|c|c|c|c|c|c|c|c|}
\hline & & (1) & (2) & $(3)=(2)-(1)$ & $(4)=1 / 2^{\star}(3)$ & $(5)=(1)+(4)$ & $(6)=(4) /(5)$ \\
\hline $\begin{array}{l}\text { Currency } \\
\text { pair }\end{array}$ & period & $\begin{array}{l}\text { Spread of } \\
\text { spot } \\
\text { exchange } \\
\text { rate }\end{array}$ & $\begin{array}{l}\text { Spread of 1- } \\
\text { month } \\
\text { forward } \\
\text { exchange } \\
\text { rate }\end{array}$ & $\begin{array}{l}\text { Forward } \\
\text { spread due } \\
\text { to swap } \\
\text { points }\end{array}$ & $\begin{array}{l}\text { 1/2-times } \\
\text { the previous } \\
\text { column: } \\
\text { transaction } \\
\text { cost of a } \\
\text { roll-over } \\
\text { position }\end{array}$ & $\begin{array}{c}\text { Transaction } \\
\text { cost of a } \\
\text { new position }\end{array}$ & $\begin{array}{c}\text { Transaction } \\
\text { cost of a } \\
\text { roll-over } \\
\text { position in } \\
\text { percent of } \\
\text { transaction } \\
\text { cost of a } \\
\text { new position }\end{array}$ \\
\hline GBPUSD & $1976-1984$ & 0.069 & 0.112 & 0.043 & 0.022 & 0.090 & $24 \%$ \\
\hline & 1985-1991 & 0.063 & 0.080 & 0.017 & 0.008 & 0.072 & $12 \%$ \\
\hline & 1992-1998 & 0.055 & 0.065 & 0.010 & 0.005 & 0.060 & $9 \%$ \\
\hline & 1999-2008 & 0.026 & 0.029 & 0.002 & 0.001 & 0.027 & $4 \%$ \\
\hline GBPDEM & $1976-1984$ & 0.239 & 0.424 & 0.185 & 0.092 & 0.332 & $28 \%$ \\
\hline & 1985-1991 & 0.232 & 0.302 & 0.069 & 0.035 & 0.267 & $13 \%$ \\
\hline & 1992-1998 & 0.123 & 0.153 & 0.029 & 0.015 & 0.138 & $11 \%$ \\
\hline & 1999-2008 & 0.058 & 0.063 & 0.005 & 0.002 & 0.061 & $4 \%$ \\
\hline GBPJPY & 1976-1984 & 0.326 & 0.383 & 0.057 & 0.028 & 0.354 & $8 \%$ \\
\hline & 1985-1991 & 0.408 & 0.492 & 0.084 & 0.042 & 0.450 & $9 \%$ \\
\hline & 1992-1998 & 0.233 & 0.270 & 0.037 & 0.018 & 0.251 & $7 \%$ \\
\hline & 1999-2008 & 0.065 & 0.071 & 0.006 & 0.003 & 0.068 & $4 \%$ \\
\hline GBPCHF & $1976-1984$ & 0.276 & 0.490 & 0.215 & 0.107 & 0.383 & $28 \%$ \\
\hline & $1985-1991$ & 0.378 & 0.467 & 0.090 & 0.045 & 0.422 & $11 \%$ \\
\hline & 1992-1998 & 0.203 & 0.245 & 0.042 & 0.021 & 0.224 & $9 \%$ \\
\hline & 1999-2008 & 0.084 & 0.091 & 0.007 & 0.003 & 0.088 & $4 \%$ \\
\hline GBPCAD & 1976-1984 & 0.049 & 0.117 & 0.068 & 0.034 & 0.083 & $41 \%$ \\
\hline & 1985-1991 & 0.087 & 0.132 & 0.045 & 0.023 & 0.109 & $21 \%$ \\
\hline & 1992-1998 & 0.080 & 0.108 & 0.028 & 0.014 & 0.094 & $15 \%$ \\
\hline & 1999-2008 & 0.070 & 0.076 & 0.006 & 0.003 & 0.073 & $4 \%$ \\
\hline GBPAUD & 1992-1998 & 0.119 & 0.151 & 0.032 & 0.016 & 0.135 & $12 \%$ \\
\hline & 1999-2008 & 0.091 & 0.097 & 0.006 & 0.003 & 0.094 & $3 \%$ \\
\hline GBPNZD & $1992-1998$ & 0.154 & 0.188 & 0.034 & 0.017 & 0.171 & $10 \%$ \\
\hline & 1999-2008 & 0.133 & 0.143 & 0.010 & 0.005 & 0.138 & $4 \%$ \\
\hline GBPDKK & $1976-1984$ & 0.092 & 0.234 & 0.142 & 0.071 & 0.163 & $44 \%$ \\
\hline & $1985-1991$ & 0.085 & 0.155 & 0.070 & 0.035 & 0.120 & $29 \%$ \\
\hline & 1992-1998 & 0.101 & 0.184 & 0.083 & 0.042 & 0.143 & $29 \%$ \\
\hline & 1999-2008 & 0.061 & 0.071 & 0.010 & 0.005 & 0.066 & $8 \%$ \\
\hline GBPSEK & 1976-1984 & 0.116 & 0.278 & 0.162 & 0.081 & 0.197 & $41 \%$ \\
\hline & 1985-1991 & 0.095 & 0.142 & 0.048 & 0.024 & 0.118 & $20 \%$ \\
\hline & 1992-1998 & 0.140 & 0.188 & 0.048 & 0.024 & 0.164 & $15 \%$ \\
\hline & 1999-2008 & 0.103 & 0.110 & 0.008 & 0.004 & 0.106 & $4 \%$ \\
\hline GBPNOK & $1976-1984$ & 0.108 & 0.276 & 0.168 & 0.084 & 0.192 & $44 \%$ \\
\hline & 1985-1991 & 0.089 & 0.150 & 0.061 & 0.030 & 0.120 & $25 \%$ \\
\hline & 1992-1998 & 0.104 & 0.173 & 0.069 & 0.035 & 0.138 & $25 \%$ \\
\hline & 1999-2008 & 0.101 & 0.112 & 0.010 & 0.005 & 0.107 & $5 \%$ \\
\hline
\end{tabular}

Note. Values shown in the first two data columns correspond to $100 \cdot \ln \left(\mathrm{S}_{\mathrm{t}} \mathrm{a} / \mathrm{S}_{\mathrm{t}} \mathrm{b}\right)$ and $100 \cdot \ln \left(F_{t}^{a} / F_{t}^{b}\right)$, respectively. See section 3.1 of the main text and Appendix A.1 for the definition and interpretation of transaction costs. Spreads of GBPDEM, GBPCHF and 
GBPJPY are shown as these are included in the database: see the description of their corrections in Section 4.

Table A.3.3

Transaction costs of Euro rates

\begin{tabular}{|c|c|c|c|c|c|c|c|}
\hline & & (1) & (2) & $(3)=(2)-(1)$ & $(4)=1 / 2^{\star}(3)$ & $(5)=(1)+(4)$ & $(6)=(4) /(5)$ \\
\hline $\begin{array}{l}\text { Currency } \\
\text { pair }\end{array}$ & period & $\begin{array}{l}\text { Spread of } \\
\text { spot } \\
\text { exchange } \\
\text { rate }\end{array}$ & $\begin{array}{l}\text { Spread of 1- } \\
\text { month } \\
\text { forward } \\
\text { exchange } \\
\text { rate }\end{array}$ & $\begin{array}{l}\text { Forward } \\
\text { spread due } \\
\text { to swap } \\
\text { points }\end{array}$ & $\begin{array}{l}\text { 1/2-times } \\
\text { the previous } \\
\text { column: } \\
\text { transaction } \\
\text { cost of a } \\
\text { roll-over } \\
\text { position }\end{array}$ & $\begin{array}{c}\text { Transaction } \\
\text { cost of a } \\
\text { new position }\end{array}$ & $\begin{array}{c}\text { Transaction } \\
\text { cost of a } \\
\text { roll-over } \\
\text { position in } \\
\text { percent of } \\
\text { transaction } \\
\text { cost of a } \\
\text { new position }\end{array}$ \\
\hline EURUSD & 1999-2008 & 0.045 & 0.061 & 0.016 & 0.008 & 0.053 & $15 \%$ \\
\hline EURGBP & $1999-2008$ & 0.059 & 0.063 & 0.004 & 0.002 & 0.061 & $3 \%$ \\
\hline EURJPY & 1999-2008 & 0.072 & 0.077 & 0.005 & 0.003 & 0.074 & $4 \%$ \\
\hline EURCHF & $1999-2008$ & 0.049 & 0.097 & 0.048 & 0.024 & 0.073 & $33 \%$ \\
\hline EURCAD & 1999-2008 & 0.076 & 0.081 & 0.00 & 0.0 & 0.079 & $4 \%$ \\
\hline EURAUD & $1999-2008$ & 0.098 & 0.104 & 0.006 & 0.0 & 0.101 & $3 \%$ \\
\hline EURNZD & 1999-2008 & 0.139 & 0.149 & 0.010 & 0.005 & 0.144 & $3 \%$ \\
\hline EURDKK & 1999-2008 & 0.025 & 0.077 & 0.052 & 0.026 & 0.051 & $51 \%$ \\
\hline EURSEK & $1999-2008$ & 0.067 & 0.116 & 0.049 & 0.025 & 0.092 & $27 \%$ \\
\hline EURNOK & $1999-2008$ & 0.066 & 0.118 & 0.052 & 0.026 & 0.092 & $28 \%$ \\
\hline
\end{tabular}

Note. Values shown in the first two data columns correspond to $100 \cdot \ln \left(\mathrm{S}_{\mathrm{t}}^{\mathrm{a}} / \mathrm{S}_{\mathrm{t}} \mathrm{b}\right)$ and $100 \cdot \ln \left(F_{t}{ }^{a} / F_{t}^{b}\right)$, respectively. See section 3.1 of the main text and Appendix A.1 for the definition and interpretation of transaction costs. 
Figure 1

Cumulative returns to 100 initial non-leveraged carry trade positions in the base currency (without transaction costs and the interest income of collateral), January 1976 - April 2008

\section{Panel A: All currency pairs and portfolios}
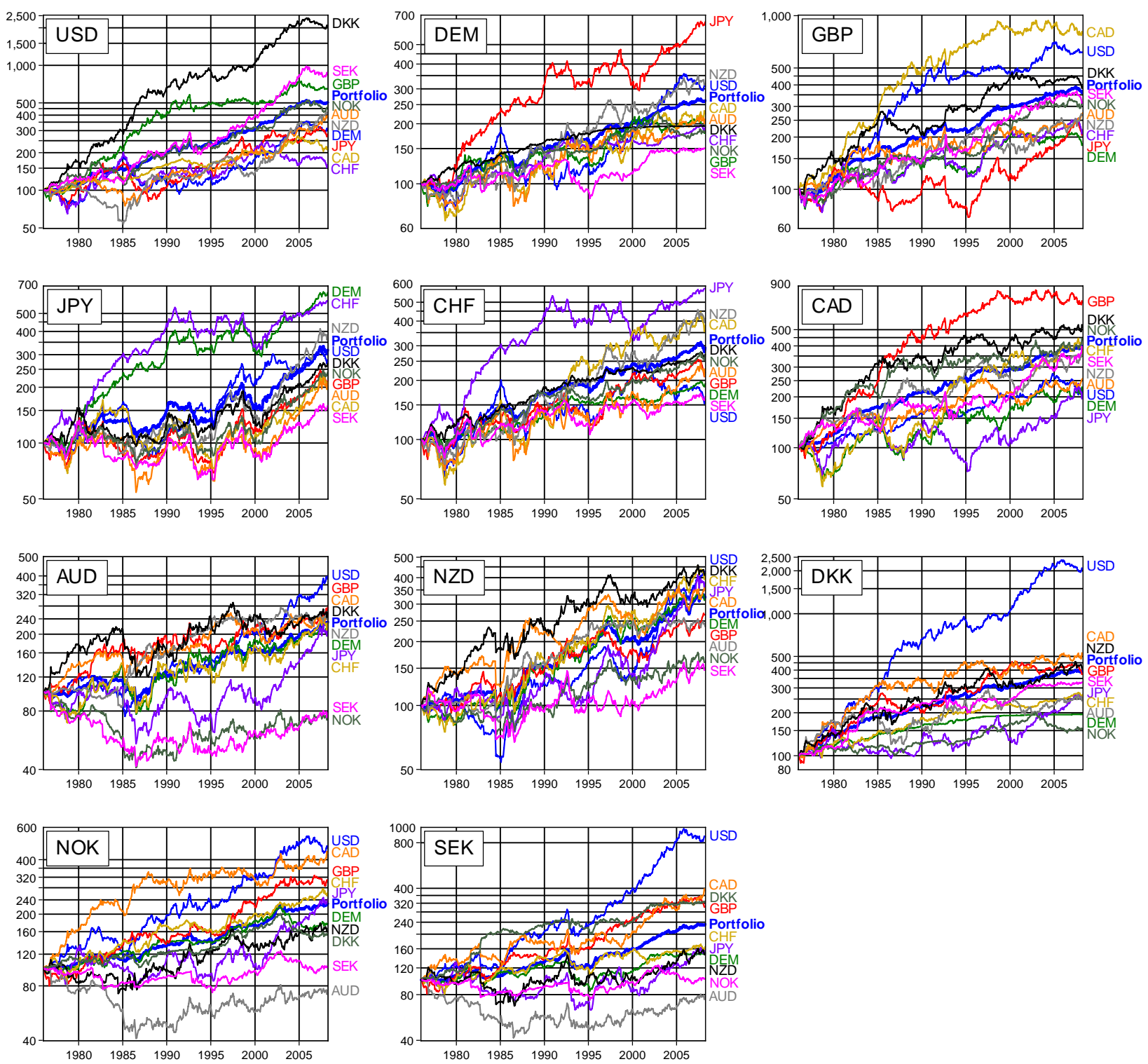


\section{Panel B: Portfolios only}

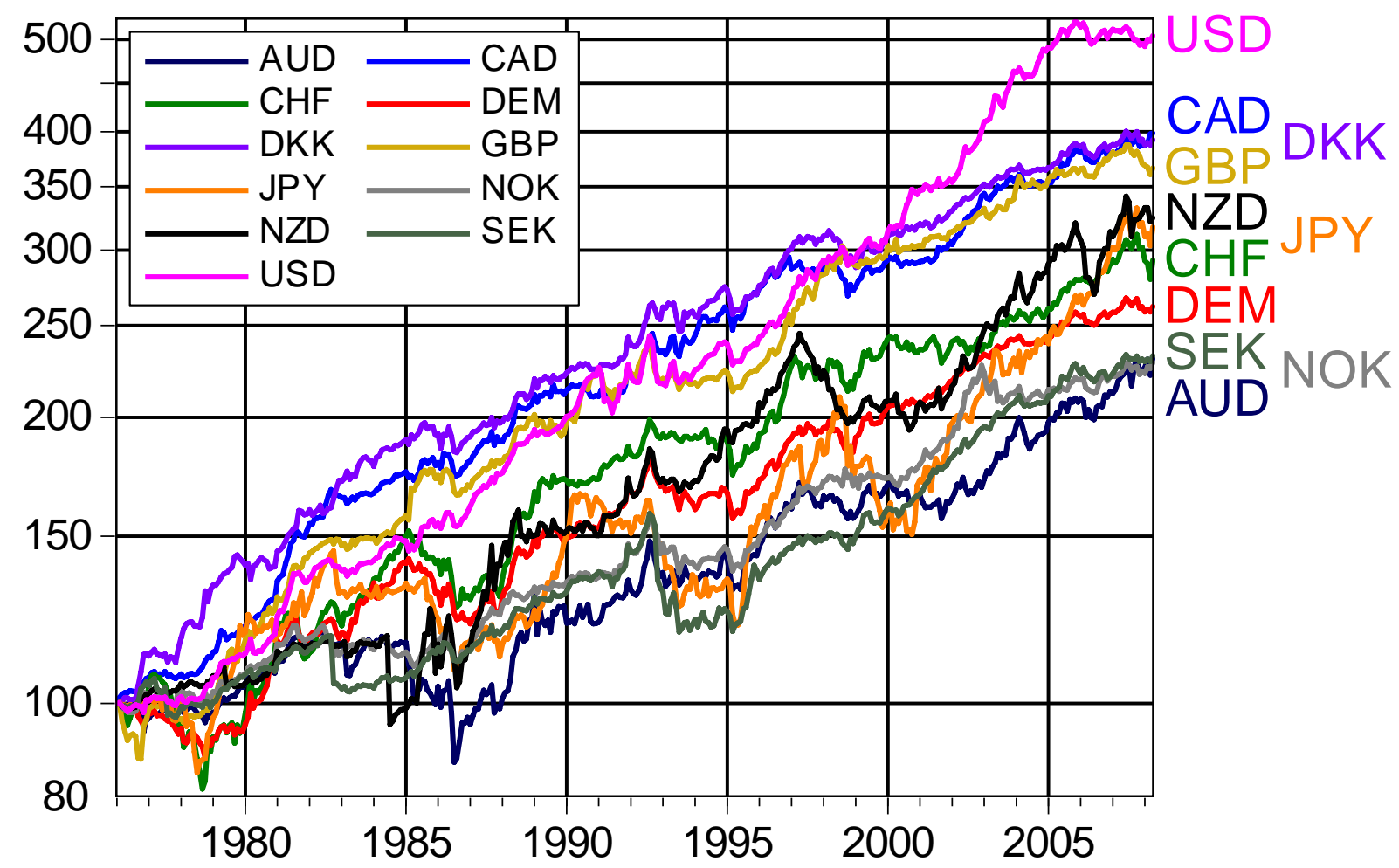

Note. The eleven panels correspond to the eleven currencies indicated on the top-left corner of the panels, which are used as base currencies against the other ten counter currencies. The portfolio shown in each panel includes the ten other currencies as counter currencies with equal weights. 
Figure 2

\section{Average annualized (compounded) return to carry trade positions as a function of leverage, when margin requirement is 4 percent (considering transaction costs, but not the interest income of collateral), J anuary 1976 - April 2008}
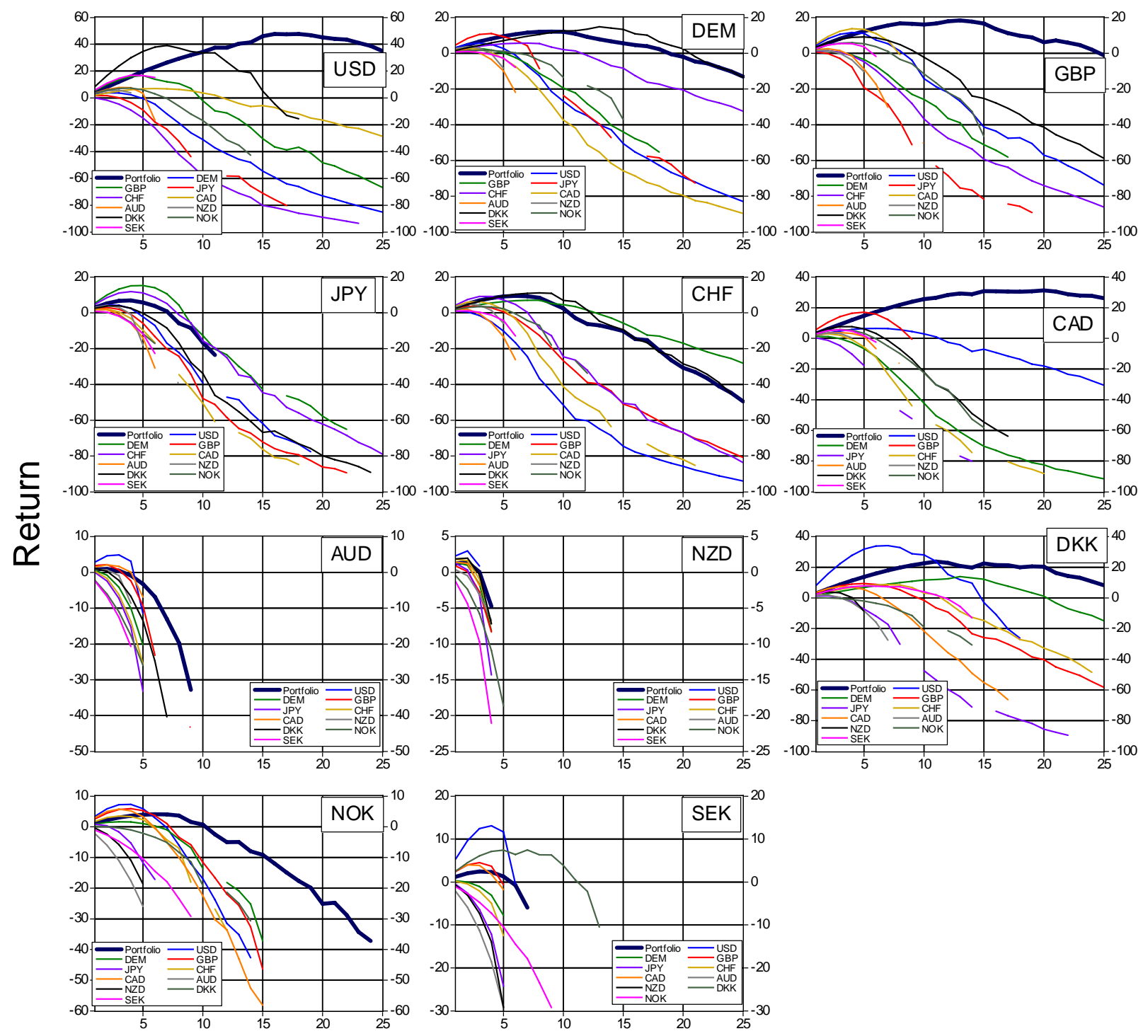

\section{Leverage}

Note. The eleven panels correspond to the eleven currencies indicated on the top-right corner of the panels, which are used as base currencies against the other ten counter currencies. The portfolio shown in each panel includes the ten other currencies as counter currencies with equal weights. When a data point is missing, the carry trade strategy went bankrupt at a day during the sample period. 
Figure 3

Sharpe ratio of monthly logarithmic returns of carry trade positions as a function of leverage, when margin requirement is 4 percent (considering transaction costs, but not the interest income of collateral), J anuary 1976 April 2008
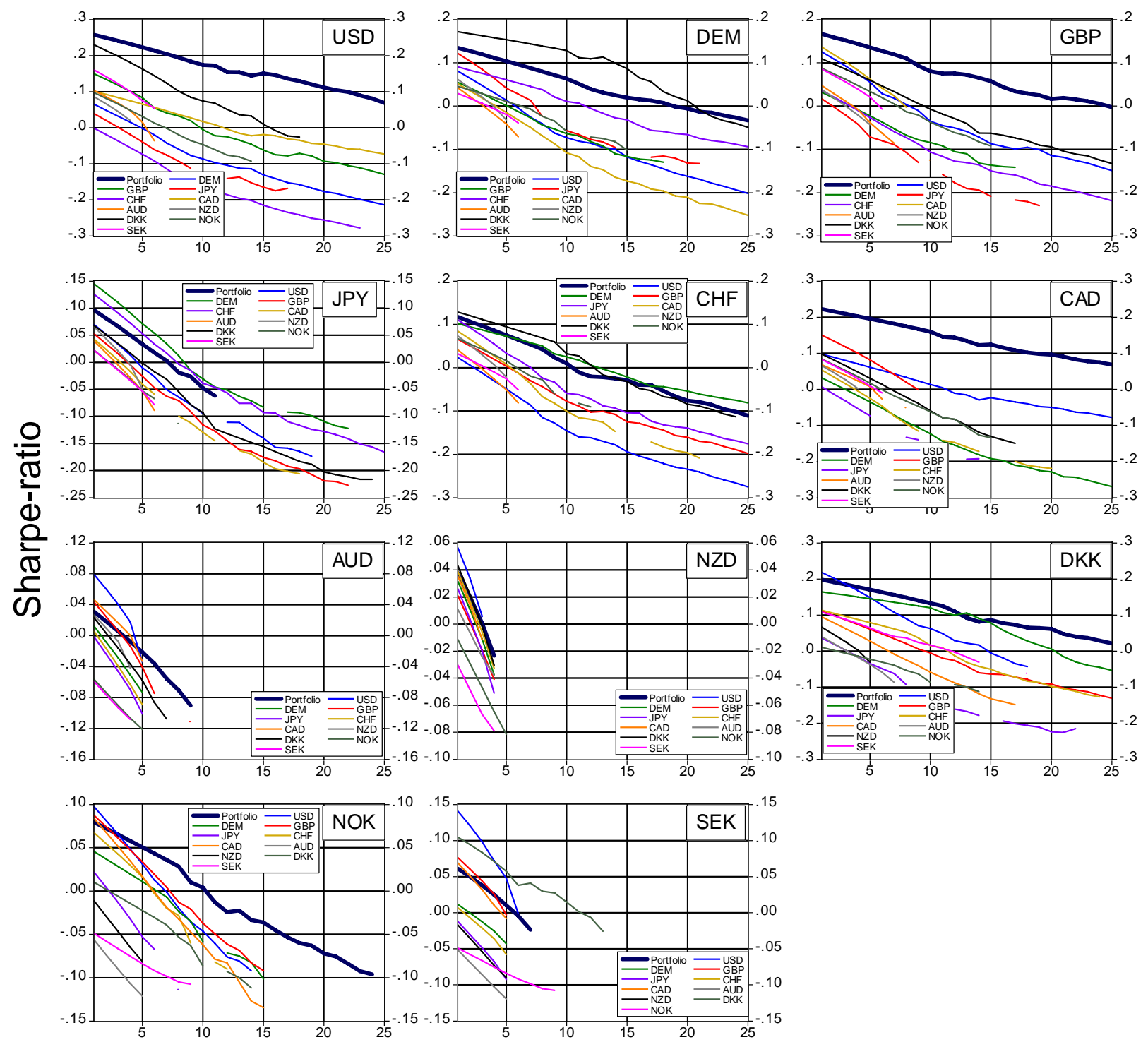

Leverage

Note. The eleven panels correspond to the eleven currencies indicated on the top-right corner of the panels, which are used as base currencies against the other ten counter currencies. The portfolio shown in each panel includes the ten other currencies as counter currencies with equal weights. When a data point is missing, the carry trade strategy went bankrupt at a day during the sample period. 
Figure 4

Skewness of monthly logarithmic returns of carry trade positions as a function of leverage, when margin requirement is 4 percent (considering transaction costs, but not the interest income of collateral), J anuary 1976 - April 2008
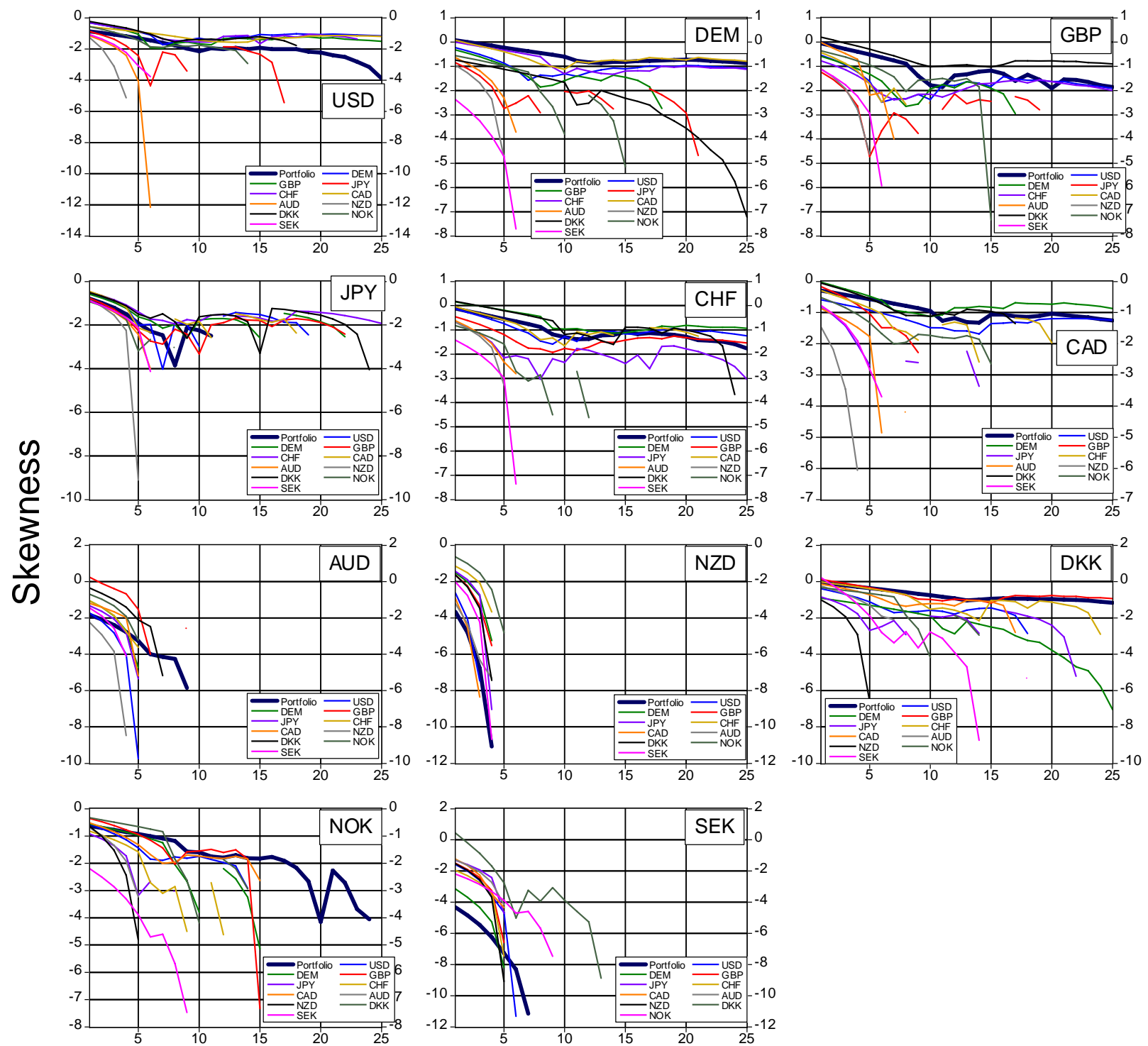

\section{Leverage}

Note. The eleven panels correspond to the eleven currencies indicated on the top-right corner of the panels, which are used as base currencies against the other ten counter currencies. The portfolio shown in each panel includes the ten other currencies as counter currencies with equal weights. When a data point is missing, the carry trade strategy went bankrupt at a day during the sample period. 
Figure 5

Kurtosis of monthly logarithmic returns of carry trade positions as a function of leverage, when margin requirement is 4 percent (considering transaction costs, but not the interest income of collateral), J anuary 1976 - April 2008
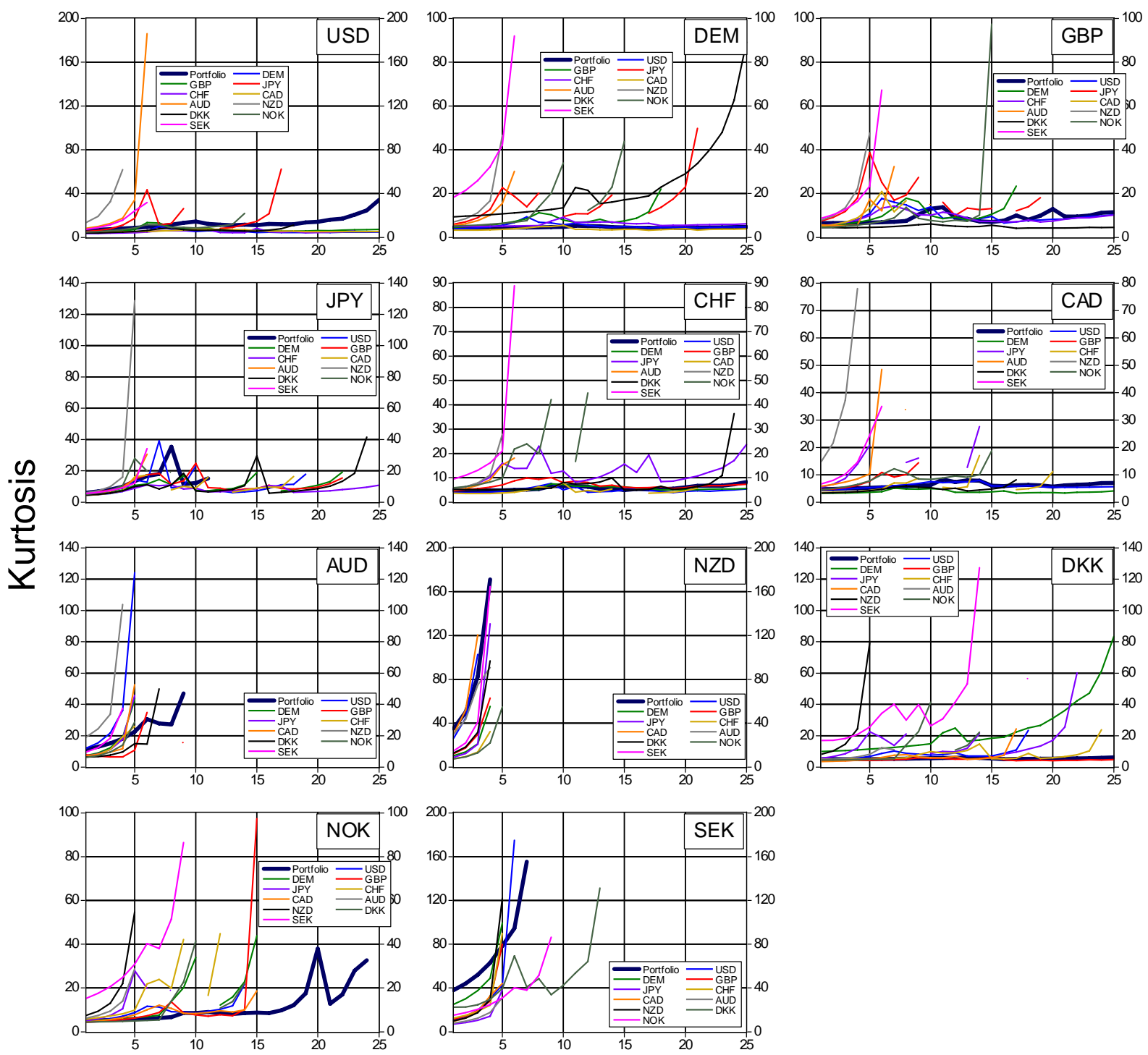

Leverage

Note. The eleven panels correspond to the eleven currencies indicated on the top-right corner of the panels, which are used as base currencies against the other ten counter currencies. The portfolio shown in each panel includes the ten other currencies as counter currencies with equal weights. When a data point is missing, the carry trade strategy went bankrupt at a day during the sample period. 
Figure 6

Monthly percentage return to carry trade positions as a function of leverage, when margin requirement is 4 percent (considering transaction costs, but not the interest income of collateral), J anuary 1976 - April 2008

\section{(A) USDDKK}

Leverage $=1$
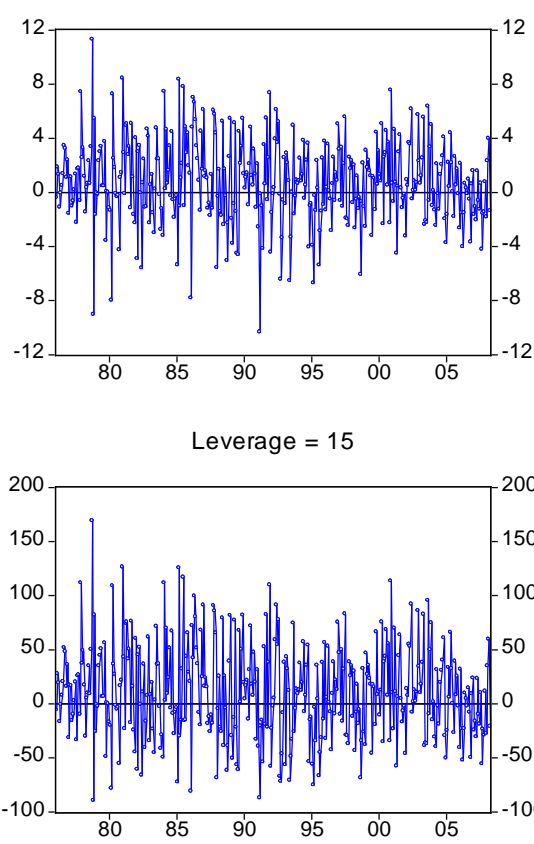

Leverage $=5$

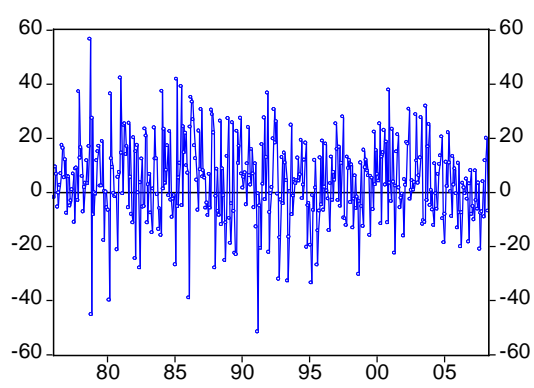

Leverage $=20$

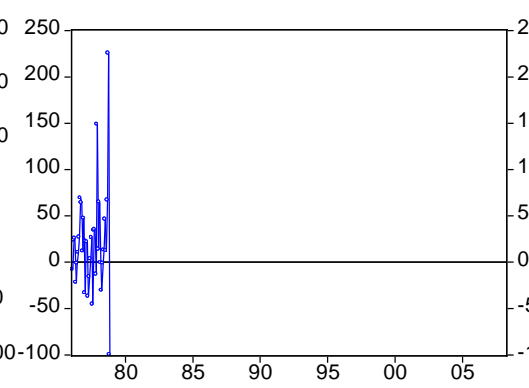

Leverage $=10$

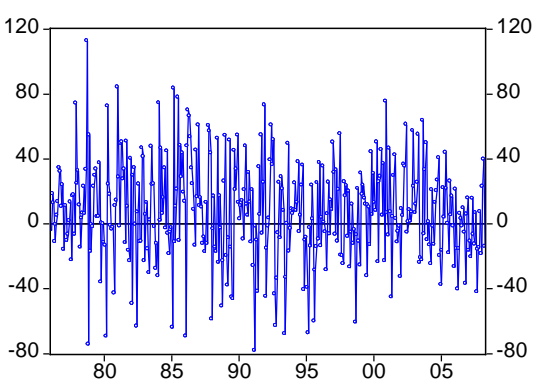

(B) USD-based portfolio
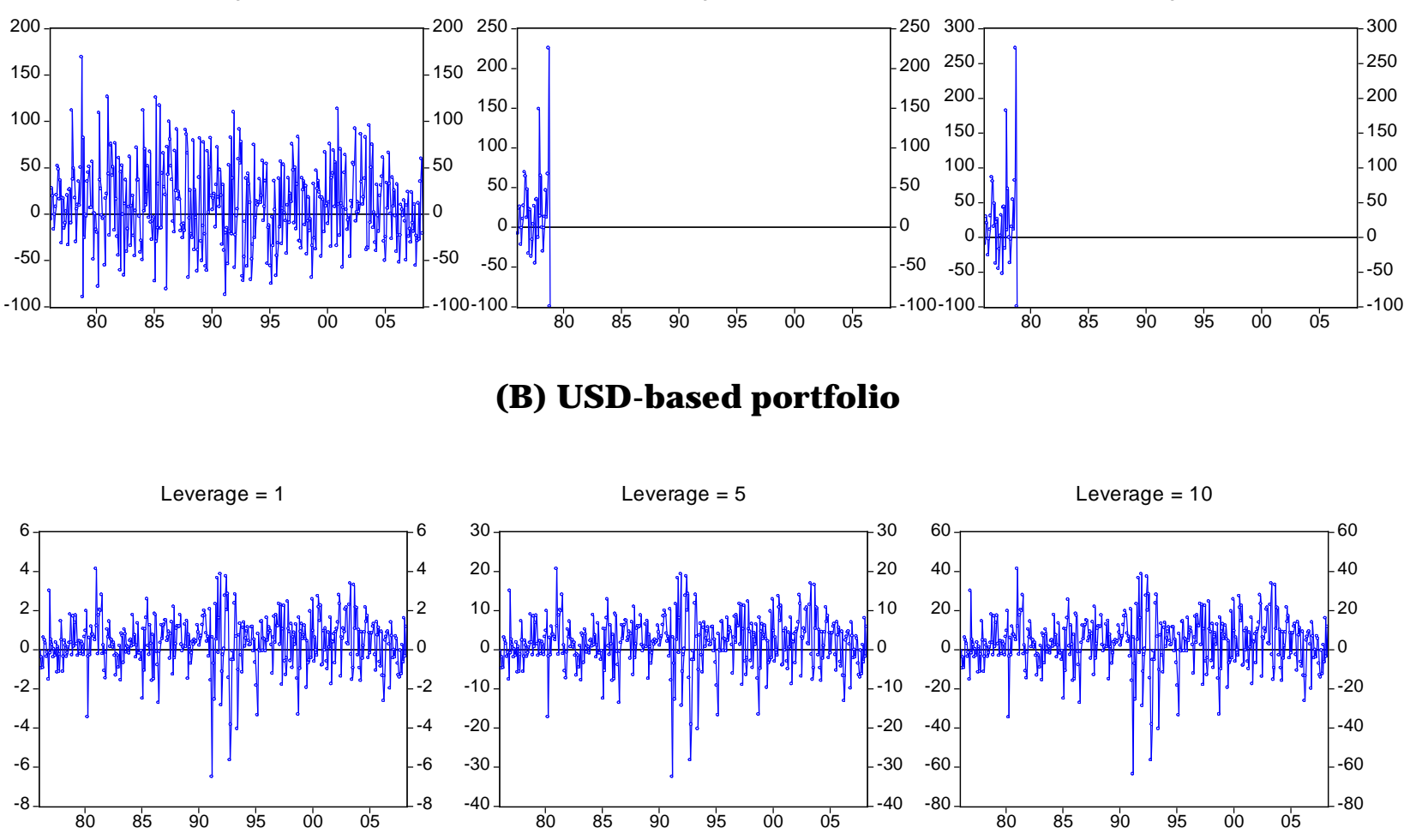

Leverage $=15$

Leverage $=20$
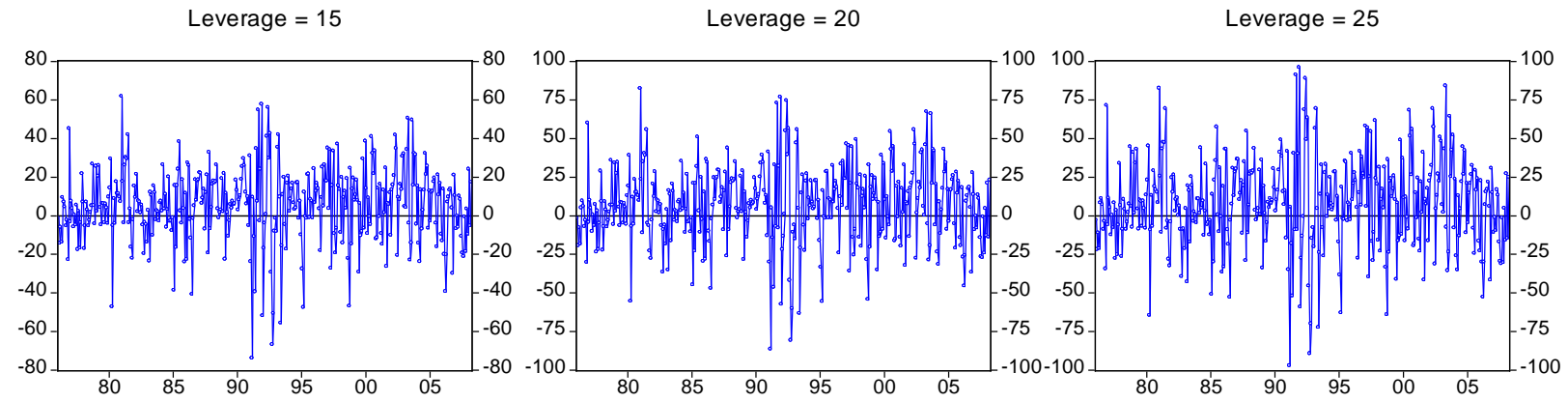
Table 1

$\beta$ parameter estimates of the Fama regression for testing uncovered interest rate parity

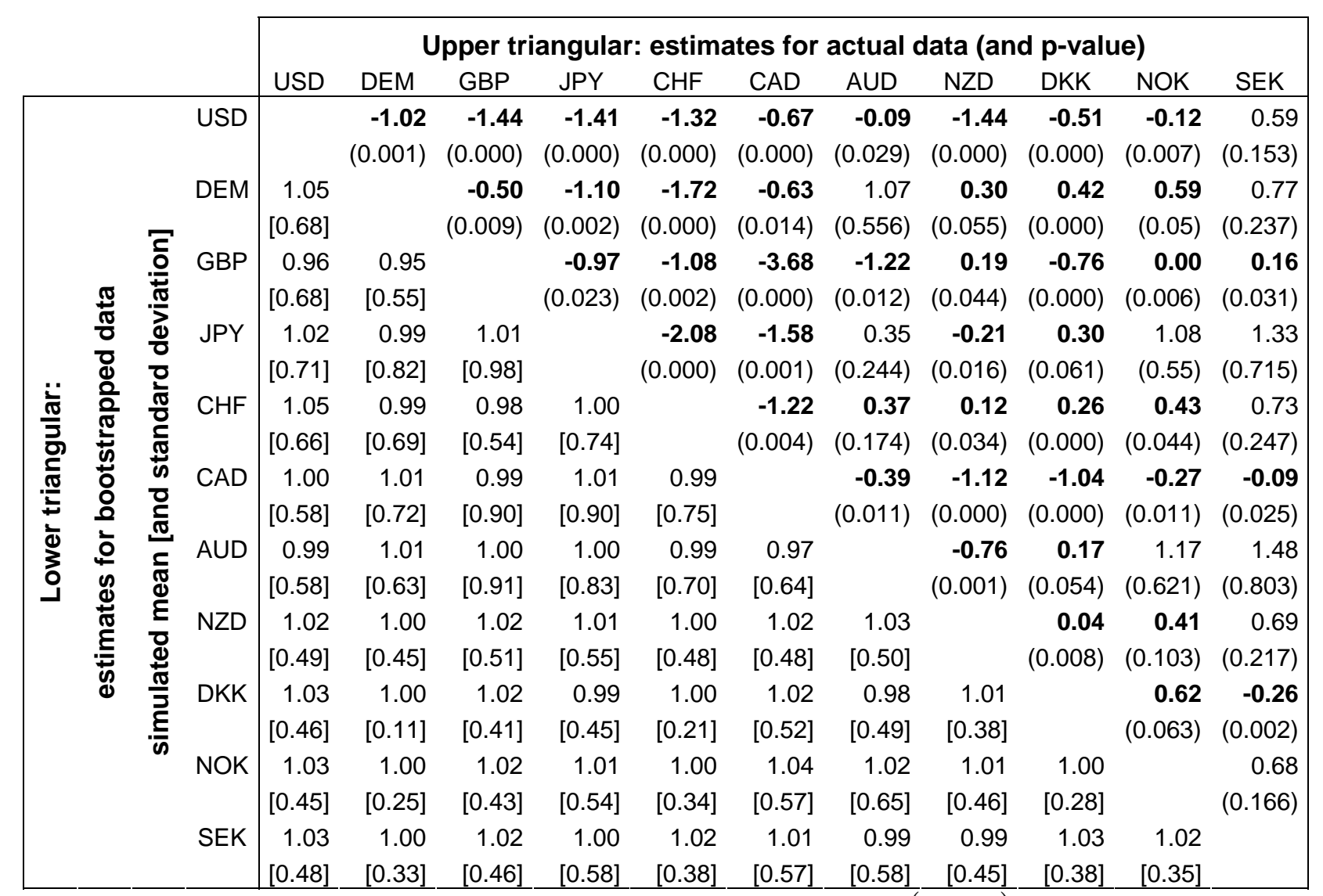

Note. The estimated Fama (1984) regression is $\Delta s_{t+1}=\alpha+\beta\left(f_{t}-s_{t}\right)+\varepsilon_{t+1}$, where $s_{t}$ and $f_{t}$ are the natural logarithm of spot and forward mid rates, respectively. Values in the upper triangular are the estimates obtained for actual data (and in brackets the p-values are shown for the hypothesis test that $\beta=1$ against the one-sided alternative that $\beta<1$, using the bootstrap distribution of the estimated $\beta$ coefficient derived from the 1000 bootstrap samples for $s_{t}$ and $f_{t}$ as described in Section 3.4). Parameter estimates that are significantly smaller than 1 are in bold. The lower triangular of the matrix shows the mean of estimated $\beta$ coefficients received for the 1000 bootstrap samples [with their standard deviation in squared brackets]. 
Table 2

\section{Cumulative value of an initial 100 non-leveraged carry trade position in the base currency from J anuary 1976 to April 2008}

\begin{tabular}{|c|c|c|c|c|c|c|c|c|c|c|c|c|c|}
\hline & \multicolumn{12}{|c|}{ Upper triangular: without transaction costs } \\
\hline & & USD & DEM & GBP & JPY & $\mathrm{CHF}$ & CAD & AUD & NZD & DKK & NOK & SEK & Portfolio \\
\hline \multirow{24}{*}{ 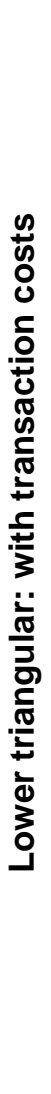 } & \multirow[t]{2}{*}{ USD } & & 308.9 & 650.6 & 282.0 & 159.3 & 216.2 & 396.1 & 413.5 & 2062.6 & 458.5 & 866.7 & 504.7 \\
\hline & & & $(0.019)$ & $(0.010)$ & $(0.070)$ & $(0.301)$ & $(0.016)$ & $(0.049)$ & $(0.188)$ & $(0.000)$ & $(0.039)$ & $(0.001)$ & $(0.000)$ \\
\hline & \multirow[t]{2}{*}{ DEM } & 220.3 & & 182.3 & 650.1 & 192.4 & 224.2 & 211.6 & 319.0 & 195.2 & 183.9 & 151.2 & 261.7 \\
\hline & & $(0.065)$ & & $(0.301)$ & $(0.003)$ & $(0.100)$ & $(0.111)$ & $(0.238)$ & $(0.238)$ & $(0.058)$ & $(0.360)$ & $(0.236)$ & (0.009) \\
\hline & \multirow[t]{2}{*}{ GBP } & 426.1 & 136.8 & & 215.8 & 219.7 & 791.3 & 275.4 & 267.5 & 388.6 & 314.2 & 316.4 & 366.2 \\
\hline & & $(0.038)$ & $(0.555)$ & & $(0.517)$ & $(0.503)$ & $(0.002)$ & $(0.072)$ & (0.104) & $(0.002)$ & $(0.006)$ & $(0.014)$ & (0.001) \\
\hline & \multirow[t]{2}{*}{ JPY } & 169.2 & 442.9 & 126.4 & & 584.9 & 208.9 & 213.4 & 379.6 & 268.5 & 241.8 & 159.2 & 317.6 \\
\hline & & $(0.242)$ & $(0.022)$ & $(0.802)$ & & $(0.000)$ & $(0.314)$ & $(0.470)$ & (0.379) & $(0.407)$ & $(0.513)$ & $(0.485)$ & (0.172) \\
\hline & \multirow[t]{2}{*}{$\mathrm{CHF}$} & 98.7 & 163.5 & 149.7 & 387.9 & & 380.1 & 229.4 & 414.5 & 271.0 & 266.0 & 165.3 & 293.0 \\
\hline & & $(0.584)$ & $(0.265)$ & $(0.759)$ & $(0.017)$ & & $(0.082)$ & $(0.397)$ & $(0.313)$ & $(0.262)$ & $(0.399)$ & $(0.456)$ & (0.097) \\
\hline & \multirow[t]{2}{*}{ CAD } & 185.3 & 148.9 & 521.5 & 110.0 & 212.8 & & 257.8 & 350.3 & 514.4 & 433.5 & 385.8 & 398.4 \\
\hline & & $(0.068)$ & $(0.283)$ & $(0.012)$ & $(0.675)$ & $(0.287)$ & & $(0.071)$ & $(0.127)$ & $(0.003)$ & $(0.014)$ & (0.010) & (0.000) \\
\hline & \multirow[t]{2}{*}{ AUD } & 253.7 & 119.1 & 183.5 & 97.2 & 109.2 & 161.9 & & 235.6 & 257.7 & 74.9 & 77.8 & 231.1 \\
\hline & & $(0.170)$ & $(0.554)$ & (0.181) & $(0.829)$ & $(0.784)$ & $(0.292)$ & & (0.108) & (0.089) & $(0.634)$ & $(0.692)$ & (0.110) \\
\hline & \multirow[t]{2}{*}{ NZD } & 209.4 & 156.5 & 132.6 & 149.5 & 179.8 & 157.1 & 112.7 & & 418.5 & 160.1 & 147.9 & 324.5 \\
\hline & & $(0.595)$ & $(0.630)$ & $(0.441)$ & (0.819) & $(0.728)$ & $(0.553)$ & $(0.523)$ & & $(0.023)$ & $(0.276)$ & $(0.446)$ & (0.104) \\
\hline & \multirow[t]{2}{*}{ DKK } & 1269.4 & 159.9 & 282.4 & 155.0 & 200.3 & 319.4 & 139.0 & 182.9 & & 155.3 & 329.1 & 392.2 \\
\hline & & $(0.000)$ & $(0.414)$ & $(0.017)$ & $(0.757)$ & $(0.631)$ & (0.038) & $(0.312)$ & $(0.231)$ & & (0.063) & $(0.000)$ & (0.000) \\
\hline & \multirow[t]{2}{*}{ NOK } & 297.4 & 132.8 & 228.1 & 132.1 & 177.8 & 260.6 & 41.3 & 70.1 & 106.2 & & 101.9 & 228.5 \\
\hline & & $(0.138)$ & $(0.733)$ & $(0.040)$ & $(0.833)$ & $(0.745)$ & $(0.104)$ & $(0.909)$ & $(0.753)$ & $(0.406)$ & & $(0.552)$ & (0.038) \\
\hline & \multirow[t]{2}{*}{ SEK } & 540.0 & 109.8 & 218.5 & 84.6 & 106.8 & 231.0 & 43.4 & 65.2 & 218.2 & 67.4 & & 232.2 \\
\hline & & $(0.006)$ & $(0.571)$ & $(0.083)$ & $(0.840)$ & $(0.806)$ & $(0.088)$ & $(0.915)$ & $(0.832)$ & $(0.011)$ & $(0.895)$ & & $(0.004)$ \\
\hline & \multirow[t]{2}{*}{ Portfolio } & 370.0 & 215.2 & 252.0 & 266.4 & 239.5 & 273.0 & 130.4 & 148.1 & 263.3 & 147.6 & 147.1 & \\
\hline & & $(0.0$ & 5) & $(0.029)$ & $(0.264)$ & 0) & $(0.001)$ & $(0.645)$ & (0.699) & $(0.0$ & $(0.5$ & $(0.364)$ & \\
\hline
\end{tabular}

Note: The upper (lower) triangular of the matrix shows returns without (with) transaction costs. Portfolios include the ten other currencies as counter currencies with equal weights against the base currency indicated in the text in the top row and left column of the table. When transaction costs are included (not included) the selection of the base currency in a currency pair matters (does not matter). Results shown in the lower triangular are the smaller of the two results corresponding to the two base currencies. p-values are shown (in brackets) for the hypothesis test that the cumulative excess return is zero against the onesided alternative that it is positive (i.e. the values shown are larger than 100), using the bootstrap distribution of this statistics derived from the 1000 bootstrap samples as described in Section 3.4. Returns shown are excess returns over the risk free interest rate because they do not include the interest income of collateral. Significant values are in bold. 
Table 3

Sharpe ratio of monthly logarithm excess returns of non-leveraged carry trade positions in J anuary 1976 - April 2008

\begin{tabular}{|c|c|c|c|c|c|c|c|c|c|c|c|c|c|}
\hline & \multicolumn{12}{|c|}{ Upper triangular: without transaction costs } \\
\hline & & $\mathrm{D}$ & DEM & GBP & JPY & $\mathrm{CHF}$ & CAD & AUD & NZD & DKK & JOK & SEK & Portfolio \\
\hline \multirow{24}{*}{ 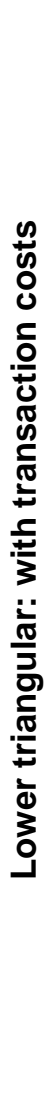 } & \multirow[t]{2}{*}{ USD } & & 0.09 & 0.16 & 0.08 & 0.03 & 0.12 & 0.12 & 0.11 & 0.26 & 0.14 & 0.19 & 0.32 \\
\hline & & & $(0.020)$ & $(0.009)$ & $(0.069)$ & $.301)$ & $(0.015)$ & $.053)$ & $(0.207)$ & $0.000)$ & $.041)$ & $(0.000)$ & $0.000)$ \\
\hline & \multirow[t]{2}{*}{ DEM } & 0.06 & & 0.06 & 0.16 & 0.12 & 0.06 & 0.05 & 0.09 & 0.24 & 0.10 & 0.05 & 0.17 \\
\hline & & (0.064) & & $(0.306)$ & $(0.003)$ & $.104)$ & (0.109) & $0.244)$ & $(0.237)$ & $0.068)$ & $(0.367)$ & $(0.252)$ & (0.036) \\
\hline & \multirow[t]{2}{*}{ GBP } & 0.13 & 0.03 & & 0.06 & 0.07 & 0.17 & 0.07 & 0.08 & 0.14 & 0.12 & 0.12 & 0.23 \\
\hline & & $(0.040)$ & $(0.561)$ & & $(0.526)$ & $.509)$ & (0.001) & $0.071)$ & $(0.110)$ & $0.002)$ & $(0.005)$ & $(0.017)$ & (0.002) \\
\hline & \multirow[t]{2}{*}{ JPY } & 0.04 & 0.12 & 0.02 & & 0.15 & 0.05 & 0.05 & 0.09 & 0.08 & 0.07 & 0.04 & 0.11 \\
\hline & & $(0.250)$ & $(0.023)$ & $(0.807)$ & & $(0.000)$ & $(0.314)$ & $0.478)$ & $(0.376)$ & 0.398) & $(0.511)$ & $0.486)$ & (0.204) \\
\hline & \multirow[t]{2}{*}{$\mathrm{CHF}$} & 0.0 & 0.09 & 0.04 & 0.11 & & 0.09 & 5 & 0 & & 2 & 0.05 & 0.14 \\
\hline & & (0.584) & $(0.260)$ & $.763)$ & $(0.017)$ & & (0.081) & $0.394)$ & $(0.320)$ & $.261)$ & 2) & $.469)$ & 44) \\
\hline & \multirow[t]{2}{*}{ CAD } & 0.10 & 0.03 & 0.14 & 1 & 0.05 & & 0.09 & 0.10 & 0.13 & 0.13 & 0.11 & 0.31 \\
\hline & & (0.062) & (0.281) & $(0.012)$ & $(0.677)$ & $(0.290)$ & & (0.077) & $(0.137)$ & $(0.001)$ & $(0.014)$ & (0.011) & (0.000) \\
\hline & \multirow[t]{2}{*}{ AUD } & 0.08 & 0.01 & 0.04 & 0.00 & 0.01 & 0.05 & & 0.08 & 0.07 & -0.02 & -0.02 & 0.10 \\
\hline & & (0.191) & $(0.558)$ & (0.187) & $(0.828)$ & $(0.785)$ & $(0.303)$ & & $(0.116)$ & $(0.093)$ & $(0.632)$ & (0.688) & (0.186) \\
\hline & \multirow[t]{2}{*}{ NZD } & 0.06 & 0.03 & 0.02 & 0.03 & 0.04 & 0.04 & 0.01 & & 0.11 & 0.04 & 0.03 & 0.12 \\
\hline & & (0.617) & (0.639) & $(0.449)$ & (0.819) & $(0.731)$ & $(0.570)$ & $(0.528)$ & & $(0.028)$ & $(0.280)$ & $(0.447)$ & (0.216) \\
\hline & \multirow[t]{2}{*}{ DKK } & 0.22 & 0.16 & 0.11 & 0.04 & 0.11 & 0.10 & 0.02 & 0.04 & & 0.07 & 0.16 & 0.28 \\
\hline & & (0.000) & $(0.416)$ & $(0.016)$ & $(0.759)$ & $(0.627)$ & $(0.036)$ & $(0.316)$ & $(0.247)$ & & $(0.062)$ & $(0.000)$ & (0.000) \\
\hline & \multirow[t]{2}{*}{ NOK } & 0.10 & 0.05 & 0.09 & 0.02 & 0.07 & 0.08 & -0.06 & -0.03 & 0.01 & & 0.00 & 0.17 \\
\hline & & (0.143) & $(0.737)$ & $(0.041)$ & $(0.834)$ & $(0.747)$ & $(0.106)$ & (0.901) & $(0.749)$ & $(0.405)$ & & ) & (0.072) \\
\hline & \multirow[t]{2}{*}{ SEK } & 0.14 & 0.01 & 0.08 & -0.01 & 0.01 & 0.07 & -0.06 & -0.03 & 0.10 & -0.05 & & 0.14 \\
\hline & & $(0.008)$ & $(0.572)$ & $(0.086)$ & $(0.840)$ & $(0.806)$ & $(0.096)$ & $(0.903)$ & $(0.827)$ & $(0.010)$ & $(0.882)$ & & (0.085) \\
\hline & \multirow[t]{2}{*}{ Portfolio } & 0.26 & 0.13 & 0.17 & 0.10 & 0.12 & 0.22 & 0.03 & 0.04 & 0.20 & 0.08 & 0.06 & \\
\hline & & $(0.002)$ & $(0.142)$ & $(0.058)$ & $(0.290)$ & $(0.293)$ & $(0.004)$ & $(0.687)$ & $(0.744)$ & $(0.012)$ & $(0.594)$ & $(0.539)$ & \\
\hline
\end{tabular}

Note: The upper (lower) triangular of the matrix shows Sharpe ratios without (with)

transaction costs. Portfolios include the ten other currencies as counter currencies with equal weights against the base currency indicated in the text in the top row and left column of the table. When transaction costs are included (not included) the selection of the base currency in a currency pair matters (does not matter). Results shown in the lower triangular are the smaller of the two results corresponding to the two base currencies. p-values are shown (in brackets) for the hypothesis test that the Sharpe ratio is zero against the one-sided alternative that its is positive, using the bootstrap distribution of this statistics derived from the 1000 bootstrap samples as described in Section 3.4. Sharpe ratios are calculated from excess returns over the risk free interest rate because they do not include the interest income of collateral, and hence not comparable to Sharpe ratios of other assets. Significant values are in bold. 
Table 4

Skewness and kurtosis of monthly logarithm excess returns of non-leveraged
carry trade positions in January 1976 - April 2008

\begin{tabular}{|c|c|c|c|c|c|c|c|c|c|c|c|c|c|}
\hline & \multicolumn{12}{|c|}{ Upper triangular: Skewness without (with) transaction costs } \\
\hline & & SD & DEM & GBP & JPY & $\mathrm{CHF}$ & CAD & AUD & NZD & DKK & NOK & SEK & Oortfolio \\
\hline \multirow{9}{*}{ 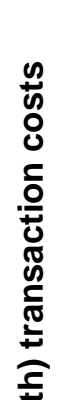 } & \multirow[t]{2}{*}{ USD } & & & & & & & & & & & 55 & -0 \\
\hline & & & $(-c$ & $(-0.40)$ & $(-0.7$ & $(-0.22)$ & $(-0.58)$ & 4) & & $(-0$. & & & $0.87)$ \\
\hline & \multirow[t]{2}{*}{ DEM } & 3.68 & & -0.31 & -0.54 & 0.17 & 0.13 & -0.60 & -0.89 & -0.47 & -0.38 & -2.33 & 0.12 \\
\hline & & (3.80) & & $(-0.46)$ & $(-0.72)$ & $(0.08)$ & $(0.02)$ & 6) & 4) & $-0.83)$ & 8) & $(-2.77)$ & D.08) \\
\hline & \multirow[t]{2}{*}{ GBP } & 4.71 & 4.60 & & -0.77 & -0.46 & -0.12 & 0.44 & -1.00 & 0.29 & -0 & -1.00 & 0.40 \\
\hline & & $(4.96)$ & $(4.85)$ & & $(-1.01)$ & $(-0.61)$ & $(-0.30)$ & (C & 7) & 7) & ) & $(-1.32)$ & $-0.05)$ \\
\hline & \multirow[t]{2}{*}{ JPY } & 4.43 & 4.92 & 5.70 & & & & & & & & -0.89 & -0.80 \\
\hline & & (4.91) & (5.47) & (6.55) & & & $(-0.65)$ & 1) & $(-\perp$. & $(-0$. & $(-U$ & $(-1.10)$ & $-0.79)$ \\
\hline & \multirow[t]{2}{*}{$\mathrm{CHF}$} & 3.83 & 5.25 & 4.68 & 4.67 & & -0.03 & -0 & -0 . & 0. & -0 & -1.39 & -0.10 \\
\hline \multirow{7}{*}{ 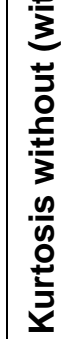 } & & (3.76) & (5.15) & (5.03) & $(5.1$ & & . & $(-0$ & & (c) & ) & $(-1$ & 1) \\
\hline & \multirow[t]{2}{*}{ CAD } & 4.33 & 3.31 & 4.51 & 4.38 & 3.59 & & & 44 & 2 & & -0.72 & -0.13 \\
\hline & & (4.47) & (3.29) & (4.81) & $(4.91)$ & (3.53) & & 4) & $(-2.20)$ & $(-0.10)$ & $(-0$. & $(-1.00)$ & $(-0.30)$ \\
\hline & \multirow[t]{2}{*}{ AUD } & 8.23 & 5.39 & 7.75 & 5.20 & 4.88 & 5.78 & & -1.99 & & & -1.03 & -1.26 \\
\hline & & .0.07) & (6.31) & (6.78) & (6.0 & $(560)$ & (6.47) & & & $(-0$. & )) & $(-1.37)$ & $(-1.83)$ \\
\hline & \multirow[t]{2}{*}{ NZD } & 13.25 & 6.90 & 7.71 & 5.97 & 5.32 & 14.56 & 17.95 & & -0 & -0.58 & -1.33 & -2.30 \\
\hline & & (19.88 & (8.67) & 10.0 & $(7.4$ & $(6.4$ & $(22.41)$ & $(24.5$ & & $(-1$ & $(-0$ & $(-1.77)$ & $(-3.67)$ \\
\hline & \multirow[t]{2}{*}{ DKK } & 3.84 & 8.01 & 4.41 & 4.49 & 5.30 & 3.27 & 5.66 & 7.91 & & -0 & 0.95 & 0.16 \\
\hline & & (4.06) & (9.63) & $(4.32)$ & (5.04) & $(515)$ & (3.4 & (5.67) & 0 45) & & 0 & (0.33) & $(-0.06)$ \\
\hline & \multirow[t]{2}{*}{ NOK } & 4.25 & 4.86 & 4.37 & 4.01 & 5.09 & 3.95 & 6.09 & 7.43 & 4.33 & & -2.15 & -0.41 \\
\hline & & (4.55) & (5.01) & (4.63) & $(4.48)$ & (5.44) & (4.25) & (7.53) & (9.57) & (4.37) & & $(-2.47)$ & $(-0.63)$ \\
\hline & \multirow[t]{2}{*}{ SEK } & 7.29 & 18.22 & 8.39 & 5.52 & 9.42 & 6.57 & 99 & 9.29 & 20.38 & 15.20 & & -3.42 \\
\hline & & (9.05) & (21.65) & 10.13) & $\left(6.3^{3}\right.$ & & & & & & & & $(-4.33)$ \\
\hline & \multirow[t]{2}{*}{ Portfolio } & 6.64 & 4.61 & 7.28 & & 4. & 4.6 & 8.8 & 20. & 5. & 4. & & \\
\hline & & (6.57) & $(4.56)$ & (6.53) & (5.99) & 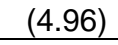 & (4.74) & (11.45) & (35.09) & (5.07) & $(5.04)$ & ) & \\
\hline
\end{tabular}

Note: The upper (lower) triangular of the matrix shows skewness (kurotis) of excess return. There are two rows for each currency pair and portfolio: the upper (lower) one shows values without (with) transaction costs. Portfolios include the ten other currencies as counter currencies with equal weights against the base currency indicated in the text in the top row and left column of the table. When transaction costs are included (not included) the selection of the base currency in a currency pair matters (does not matter). Results shown in brackets are the average of the two results corresponding to the two base currencies. 
Table 5

Maximum percentage loss of the USDDKK carry trade strategy and a USD based carry trade portfolio including ten major currencies, as a function of leverage and time (when margin requirement is 4 percent, considering transaction costs but not the interest income of collateral), J anuary 1976 - April 2008

(A) USDDKK

\begin{tabular}{|c|c|c|c|c|c|c|c|c|c|c|c|c|}
\hline & \multicolumn{12}{|c|}{ Month } \\
\hline Leverage & 1 & 2 & 3 & 4 & 5 & 6 & 7 & 8 & 9 & 10 & 11 & 12 \\
\hline 1 & -10.4 & -12.7 & -12.8 & -15.1 & -17.3 & -15.9 & -17.1 & -17.0 & -18.2 & -19.5 & -21.9 & -23.0 \\
\hline 2 & -20.7 & -24.8 & -25.1 & -29.1 & -32.8 & -30.0 & -31.9 & -31.9 & -33.8 & -36.1 & -39.8 & -41.5 \\
\hline 3 & -31.1 & -36.5 & -36.7 & -41.9 & -46.4 & -43.1 & -45.1 & -44.9 & -47.2 & -50.0 & -54.3 & -56.3 \\
\hline 4 & -41.5 & -47.5 & -47.9 & -53.6 & -58.4 & -55.0 & -57.0 & -56.0 & -58.6 & -61.5 & -66.0 & -67.9 \\
\hline 5 & -51.8 & -58.1 & -58.4 & -64.2 & -68.8 & -65.6 & -67.6 & -65.6 & -68.0 & -70.9 & -75.1 & -76.9 \\
\hline 6 & -62.2 & -68.1 & -68.4 & -73.7 & -77.8 & -75.0 & -76.8 & -75.0 & -75.8 & -78.5 & -82.3 & -83.8 \\
\hline 7 & -72.8 & -77.7 & -78.0 & -82.4 & -85.6 & -83.5 & -84.8 & -83.4 & -82.2 & -84.5 & -87.7 & -88.9 \\
\hline 8 & -78.2 & -82.7 & -82.9 & -86.9 & -89.6 & -87.9 & -89.0 & -87.8 & -87.2 & -89.2 & -91.7 & -92.7 \\
\hline 9 & -75.6 & -81.3 & -85.0 & -86.4 & -89.6 & -87.7 & -89.0 & -89.9 & -91.2 & -92.8 & -94.7 & -95.3 \\
\hline 10 & -78.3 & -84.0 & -86.1 & -88.9 & -91.8 & -90.8 & -92.0 & -94.1 & -95.0 & -96.0 & -97.2 & -97.6 \\
\hline 11 & -83.3 & -88.1 & -89.3 & -92.2 & -94.4 & -93.1 & -94.0 & -94.7 & -95.5 & -96.6 & -97.7 & -98.0 \\
\hline 12 & -87.9 & -91.7 & -91.8 & -95.0 & -96.6 & -95.7 & -96.3 & -96.6 & -97.2 & -97.9 & -98.7 & -98.9 \\
\hline 13 & -85.4 & -89.5 & -90.0 & -93.5 & -95.7 & -94.5 & -97.0 & -98.1 & -98.5 & -98.9 & -99.3 & -99.4 \\
\hline 14 & -87.4 & -90.5 & -92.6 & -94.3 & -96.4 & -95.5 & -96.9 & -97.4 & -97.9 & -98.4 & -99.1 & -99.3 \\
\hline 15 & -89.9 & -92.5 & -95.3 & -96.2 & -97.7 & -97.4 & -98.0 & -98.3 & -98.9 & -99.0 & -99.4 & -99.6 \\
\hline 16 & -93.0 & -94.6 & -95.5 & -97.2 & -98.4 & -98.3 & -98.8 & -98.5 & -99.0 & -99.2 & -99.5 & -99.7 \\
\hline 17 & -95.8 & -95.7 & -96.5 & -98.0 & -98.8 & -98.7 & -99.1 & -99.0 & -99.3 & -99.5 & -99.7 & -99.8 \\
\hline 18 & -98.3 & -96.6 & -97.6 & -97.7 & -98.6 & -98.4 & -98.9 & -99.0 & -99.3 & -99.5 & -99.7 & -99.8 \\
\hline 19 & -100.0 & -100.0 & -100.0 & -100.0 & -100.0 & -100.0 & -100.0 & -100.0 & -100.0 & -100.0 & -100.0 & -100.0 \\
\hline 20 & -100.0 & -100.0 & -100.0 & -100.0 & -100.0 & -100.0 & -100.0 & -100.0 & -100.0 & -100.0 & -100.0 & -100.0 \\
\hline 21 & -100.0 & -100.0 & -100.0 & -100.0 & -100.0 & -100.0 & -100.0 & -100.0 & -100.0 & -100.0 & -100.0 & -100.0 \\
\hline 22 & -100.0 & -100.0 & -100.0 & -100.0 & -100.0 & -100.0 & -100.0 & -100.0 & -100.0 & -100.0 & -100.0 & -100.0 \\
\hline 23 & -100.0 & -100.0 & -100.0 & -100.0 & -100.0 & -100.0 & -100.0 & -100.0 & -100.0 & -100.0 & -100.0 & -100.0 \\
\hline 24 & -100.0 & -100.0 & -100.0 & -100.0 & -100.0 & -100.0 & -100.0 & -100.0 & -100.0 & -100.0 & -100.0 & -100.0 \\
\hline 25 & -100.0 & -100.0 & -100.0 & -100.0 & -100.0 & -100.0 & -100.0 & -100.0 & -100.0 & -100.0 & -100.0 & -100.0 \\
\hline
\end{tabular}


Table 5, continued

(B) USD-based portfolio

\begin{tabular}{|c|c|c|c|c|c|c|c|c|c|c|c|c|}
\hline & \multicolumn{12}{|c|}{ Month } \\
\hline Leverage & 1 & 2 & 3 & 4 & 5 & 6 & 7 & 8 & 9 & 10 & 11 & 12 \\
\hline 1 & -6.5 & -9.3 & -10.6 & -11.1 & -11.2 & -11.7 & -9.6 & -8.4 & -9.0 & -10.3 & -11.2 & -10.6 \\
\hline 2 & -13.0 & -18.2 & -20.6 & -21.4 & -21.6 & -22.5 & -18.8 & -16.6 & -17.8 & -20.2 & -21.9 & -20.8 \\
\hline 3 & -19.5 & -26.6 & -29.8 & -31.0 & -31.2 & -32.3 & -27.6 & -24.6 & -26.5 & -29.7 & -32.0 & -30.5 \\
\hline 4 & -26.0 & -34.6 & -38.4 & -39.8 & -40.0 & -41.4 & -35.9 & -32.4 & -34.9 & -38.7 & -41.3 & -39.7 \\
\hline 5 & -32.6 & -42.2 & -46.4 & -47.9 & -48.1 & -49.6 & -43.7 & -39.9 & -43.0 & -47.2 & -50.0 & -48.2 \\
\hline 6 & -39.1 & -49.3 & -53.7 & -55.3 & -55.6 & -57.0 & -51.0 & -47.2 & -50.7 & -55.1 & -57.9 & -56.1 \\
\hline 7 & -45.6 & -56.0 & -60.5 & -62.0 & -62.3 & -63.8 & -57.8 & -54.3 & -58.0 & -62.3 & -65.1 & -63.3 \\
\hline 8 & -52.1 & -62.2 & -66.7 & -68.1 & -68.4 & -69.8 & -64.1 & -61.0 & -64.7 & -68.9 & -71.5 & -69.9 \\
\hline 9 & -58.6 & -68.0 & -72.3 & -73.6 & -73.9 & -75.2 & -69.9 & -67.4 & -71.0 & -74.8 & -77.2 & -75.7 \\
\hline 10 & -63.8 & -73.4 & -77.3 & -78.6 & -78.8 & -80.0 & -75.3 & -72.5 & -76.6 & -80.0 & -82.2 & -80.9 \\
\hline 11 & -63.1 & -77.0 & -80.7 & -81.9 & -82.1 & -83.2 & -78.8 & -73.2 & -80.5 & -83.7 & -85.6 & -84.4 \\
\hline 12 & -66.4 & -78.6 & -87.1 & -88.0 & -88.1 & -88.9 & -85.8 & -81.7 & -84.1 & -90.4 & -91.6 & -90.9 \\
\hline 13 & -68.3 & -81.7 & -88.4 & -89.3 & -89.4 & -90.2 & -87.2 & -83.1 & -85.7 & -91.0 & -92.2 & -91.5 \\
\hline 14 & -72.2 & -83.9 & -90.5 & -91.2 & -91.4 & -92.0 & -89.4 & -85.8 & -87.1 & -92.4 & -93.5 & -92.9 \\
\hline 15 & -74.2 & -83.8 & -88.6 & -89.6 & -89.7 & -90.6 & -87.3 & -84.4 & -87.7 & -91.3 & -92.7 & -91.9 \\
\hline 16 & -78.4 & -86.3 & -90.7 & -91.5 & -91.6 & -92.4 & -89.5 & -87.0 & -88.9 & -92.5 & -93.8 & -93.0 \\
\hline 17 & -80.3 & -88.0 & -92.1 & -92.9 & -93.0 & -93.7 & -91.1 & -88.7 & -90.5 & -93.8 & -94.9 & -94.3 \\
\hline 18 & -81.8 & -90.0 & -93.8 & -94.4 & -94.5 & -95.5 & -93.6 & -90.8 & -93.1 & -95.7 & -96.5 & -96.1 \\
\hline 19 & -85.1 & -91.5 & -94.9 & -95.4 & -95.8 & -96.4 & -94.8 & -92.4 & -94.8 & -96.9 & -97.5 & -97.2 \\
\hline 20 & -86.8 & -92.5 & -95.7 & -96.2 & -96.4 & -97.0 & -95.5 & -93.9 & -95.4 & -97.4 & -97.9 & -97.6 \\
\hline 21 & -89.6 & -93.0 & -96.1 & -96.6 & -96.8 & -97.3 & -96.0 & -95.4 & -95.9 & -97.7 & -98.2 & -97.9 \\
\hline 22 & -91.0 & -94.3 & -96.7 & -97.2 & -97.3 & -97.8 & -96.8 & -96.4 & -96.7 & -98.1 & -98.5 & -98.3 \\
\hline 23 & -93.5 & -95.6 & -97.2 & -97.5 & -98.1 & -98.1 & -97.7 & -97.4 & -97.3 & -98.5 & -98.8 & -98.7 \\
\hline 24 & -95.3 & -96.9 & -97.8 & -98.1 & -98.7 & -98.6 & -98.5 & -98.2 & -98.1 & -98.9 & -99.2 & -99.1 \\
\hline 25 & -97.5 & -98.4 & -98.3 & -99.0 & -99.3 & -99.1 & -99.2 & -99.1 & -99.0 & -99.2 & -99.4 & -99.3 \\
\hline
\end{tabular}




\section{REFERENCES}

Bank for International Settlements, 2007. Triennial Central Bank Survey of Foreign Exchange and Derivatives Market Activity in 2007. Bank for International Settlements: Basel.

Becker, C., Clifton, K., 2007. Hedge fund activity and carry trades. In: Bank for International Settlements, Research on global financial stability: The use of BIS international financial statistics. CGFS Papers No. 29, Bank for International Settlements: Basel, 156-175.

Belaire-Franch, J., Opong, K.K., 2005. Some evidence of random walk behavior of euro exchange rates using ranks and signs. Journal of Banking and Finance 29, 1631-1643.

Brunnermeier, M.K., Nagel, S., Pedersen, L., 2008. Carry trades and currency crashes. NBER Macroeconomics Annual 2008, Vol. 23 (forthcoming)

Burnside, C., Eichenbaum, M., Kleshchelski, I., Rebelo, S., 2008. Do peso problems explain the returns to the carry trade? NBER Working Paper 14054.

Burnside, C., Eichenbaum, M., Rebelo, S., 2007. The returns to currency speculation in emerging markets. American Economic Review 97, 333-338.

DeMiguel, V., Garlappi, L., Uppal, R., 2007. Optimal versus naive diversification: How inefficient is the $1 / \mathrm{N}$ portfolio strategy? The Review of Financial Studies (forthcoming).

Driessen, J., Laeven, L., 2007. International portfolio diversification benefits: Cross-country evidence from a local perspective. Journal of Banking and Finance 31, 1693-1712.

Dueker, M., Neely, C.J., 2007. Can Markov switching models predict excess foreign exchange returns? Journal of Banking and Finance 31, 279-296.

Dunis, C.L., Miao, J., 2007. Trading foreign exchange portfolios with volatility filters: The carry model revisited. Applied Financial Economics 17, 249-255.

Fama, E.F., 1984. Forward and spot exchange rates, Journal of Monetary Economics 14, 319338.

Farhi, E., Gabaix, X., 2008. Rare disasters and exchange rates. NBER Working Paper 13805 .

Gagnon, J.E., Chaboud, A.P., 2007. What can the data tell us about carry trades in Japanese yen? International Finance Discussion Papers No. 899, Board of Governors of the Federal Reserve System.

Galati, G., Heath, A., McGuire, P., 2007. Evidence of carry trade activity. In: BIS Quarterly Review September 2007, Bank for International Settlements: Basel, 27-41.

Hattori, M., Shin, H.S., 2007. The broad yen carry trade. IMES Discussion Paper No. 2007E-19, Bank of Japan.

Jurek, J.W., 2008. Crash-neutral currency carry trades. Mimeo, Princeton University.

Lustig, H., Roussanov, N., Verdelhan, A., 2008. Common risk factors in currency markets. NBER Working Paper 14082.

Olson, D., 2004. Have trading rule profits in the currency markets declined over time? Journal of Banking and Finance 28, 85-105.

Plantin, G., Shin, H.S., 2008. Carry trades and speculative dynamics. Mimeo, London Business School and Princeton University.

Pukthuanthong, K., Thomas III, L.R., Bazan, C., 2007. Random walk currency futures profits revisited. International Journal of Managerial Finance 3, 263-286.

Sarno, L., Taylor. M.P., 2002. The Economics of Exchange Rates. Cambridge University Press: Cambridge, UK. 
Thomas III, L.R., 1986. Random walk profits in currency futures trading. Journal of Futures Markets 6, 109-126.

Yang, J., Sub, X., Kolaric, J.W., 2008. Do euro exchange rates follow a martingale? Some outof-sample evidence. Journal of Banking and Finance 32, 729-740.

Villanueva, O.M., 2007. Forecasting currency excess returns: Can the forward bias be exploited? Journal of Financial and Quantitative Analysis 42, 963-990.

White, H., 2000. A reality check for data snooping. Econometrica 68, 1097-1126. 


\section{DISCUSSION PAPERS PUBLISHED SINCE 2006}

\section{6}

Krisztina MOLNÁR - Sergio SANTORO: Optimal Monetary Policy When Agents Are Learning. MT-DP. 2006/1

András SIMONOVITS: Social Security Reform in the US: Lessons from Hungary. MT-DP. 2006/2

Iván MAJOR - Why do (or do not) banks share customer information?. A comparison of mature private credit markets and markets in transition. MT-DP. 2006/3

Mária LACKÓ: Tax Rates with Corruption: Labour-market Effects. Empirical Crosscountry Comparisons on OECD Countries. MT-DP. 2006/4

György MOLNÁR - Zsuzsa KAPITÁNY: Mobility, Uncertainty and Subjective Well-being in Hungary. MT-DP. 2006/5

Rozália PÁL - Roman KOZHAN: Firms' investment under financing constraints. A euro area investigation. MT-DP. 2006/6

Anna IARA: Skill diffusion by temporary migration? Returns to Western European working experience in the EU accession countries. MT-DP. 2006/7

György MOLNÁR - Zsuzsa KAPITÁNY: Uncertainty and the Demand for Redistribution. MT-DP. 2006/8

Péter BENCZÚR - István KÓNYA: Nominal growth of a small open economy. MT-DP. 2006/9

Gábor VIRÁG: Outside offers and bidding costs. MT-DP. 2006/10

Péter CSÓKA - P. Jean-Jacques HERINGS - László Á. KÓCZY: Coherent Measures of Risk from a General Equilibrium Perspective. MT-DP. 2006/11

Norbert MAIER: Common Agency with Moral Hazard and Asymmetrically Informed Principals. MT-DP.2006/12

CSERES-GERGELY Zsombor - CSORBA Gergely: Múkincs vagy múködő tőke? Gondolatok a kutatási célú adatok hozzáférhetőségéről. MT-DP.2006/13

Dr. SERES Antal: Koncentráció a hazai kereskedelemben. MT-DP.2006/14

Balázs ÉGERT: Central Bank Interventions, Communication and Interest Rate Policy in Emerging European Economies. MT-DP.2006/15

Gábor BÉKÉS - Jörn KLEINERT - Farid TOUBAL: Spillovers from Multinationals to Heterogeneous Domestic Firms: Evidence from Hungary. MT-DP.2006/16

\section{7}

Mirco TONIN: Minimum Wage and Tax Evasion: Theory and Evidence. MT-DP.2007/1

Mihály LAKI: Evolution on the market of foreign language teaching services in Hungary. MT-DP.2007/2

VINCZE Péter: Vállalatok tulajdonosi irányításának változatai. MT-DP.2007/3

Péter CSÓKA - P. Jean-Jacques HERINGS - László Á. KÓCZY: Stable Allocations of Risk. MT-DP. 2007/4

Judit TEMESVÁRY: Signal Extraction and Hyperinflations with a Responsive Monetary Policy. MT-DP. 2007/5

Péter KARÁDY - Ádám REIFF: Menu Costs and Inflation Assymmetries. Some Micro Data Evidence. MT-DP. 2007/6

Mária LACKÓ: Interrelationships of the Hidden Economy and Some Visible Segments of the Labour Market. MT-DP. 2007/7

HERMANN Zoltán: Iskolai kiadási egyenlőtlenségek, 1992-2005. MT-DP.2007/8 
CSERES-GERGELY Zsombor - MOLNÁR György: Háztartási fogyasztói magatartás és jólét Magyarországon. Kísérlet egy modell adaptációjára. MT-DP.2008/1

JUHÁSZ Anikó - KÜRTI Andrea - SERES Antal - STAUDER Márta: A kereskedelem koncentrációjának hatása a kisárutermelésre és a zöldség-gyümölcs kisárutermelók alkalmazkodása. Helyzetelemzés. MT-DP. 2008/2

Ákos VALENTINYI - Berthold HERRENDORF: Measuring Factor Income Shares at the Sectoral Level. MT-DP.2008/3

Pál VALENTINY: Energy services at local and national level in the transition period in Hungary. MT-DP.2008/4

András SIMONOVITS: Underreported Earnings and Old-Age Pension: An Elementary Model. MT-DP.2008/5

Max GILLMAN - Michal KEJAK: Tax Evasion and Growth: a Banking Approach. MT-DP.2008/6

LACKÓ Mária - SEMJÉN András: Rejtett gazdaság, rejtett foglalkoztatás és a csökkentésükre irányuló kormányzati politikák - irodalomi áttekintés. MT-DP. 2008/7

LACKÓ Mária: Az adóráták és a korrupció hatása az adóbevételekre - nemzetközi összehasonlítás (OECD országok, 2000-2004). MT-DP. 2008/8

SEMJÉN András - TÓTH István János - FAZEKAS Mihály: Az EVA tapasztalatai vállalkozói interjúk alapján. MT-DP. 2008/9

SEMJÉN András - TÓTH István János - FAZEKAS Mihály: Az alkalmi munkavállalói könyves foglalkoztatás munkaadói és munkavállói interjúk tükrében. MT-DP. 2008/10

SEMJÉN András - TÓTH István János - MAKÓ Ágnes: Az alkalmi munkavállalói könyves foglalkoztatás és a rejtett gazdaság kapcsolata (Elemzés az AM könyves munkavállalók kérdőíves megkérdezése alapján). MT-DP. 2008/11

FAZEKAS Mihály: A rejtett gazdaságból való kilépés dilemmái

Esettanulmány - budapesti futárszolgálatok, 2006-2008. MT-DP. 2008/12

TÓTH István János - SEMJÉN András - MEDGYESI Márton - CZIBIK Ágnes: Egy rejtett gazdasággal kapcsolatos lakossági felmérés tapasztalatai. MT-DP. 2008/13

BÍRÓ Anikó - VINCZE János: A gazdaság fehérítése: büntetés és ösztönzés.

Költségek és hasznok egy modellszámítás tükrében. MT-DP. 2008/14

Imre FERTŐ - Károly Attila SOÓS: Marginal Intra-Industry Trade and Adjustment Costs A Hungarian-Polish Comparison. MT-DP. 2008/15

Imre FERTÓ - Károly Attila SOÓS: Duration of trade of former communist countries at the EU. MT-DP. 2008/16

FERTŐ Imre: A magyar agrárexport kereskedelmi előnyei és versenyképessége az EU piacán. MT-DP. 2008/17

Zsolt BEDÓ - Éva OZSVALD: Codes of Good Governance in Hungary. MT-DP. 2008/18

DARVAS Zsolt - SZAPÁRY György: Az euróövezet bővitése és euróbevezetési stratégiák. MT-DP. 2008/19

László Á. KÓCZY: Strategic Power Indices: Quarrelling in Coalitions. MT-DP. 2008/20

Sarolta LACZÓ: Riskiness, Risk Aversion, and Risk Sharing: Cooperation in a Dynamic Insurance Game. MT-DP. 2008/21

Discussion Papers are available at the website of Institute of Economics Hungarian Academy of Sciences: http://econ.core.hu 